\title{
Synthesis of Monthly and Annual Streamflow Records (Water Years 1950-2003) for Big Sandy, Clear, Peoples, and Beaver Creeks in the Milk River Basin, Montana
}

Scientific Investigations Report 2005-5216 


\section{Synthesis of Monthly and Annual Streamflow Records (Water Years 1950-2003) for Big Sandy, Clear, Peoples, and Beaver Creeks in the Milk River Basin, Montana}

By Charles Parrett

In cooperation with the International Joint Commission

Scientific Investigations Report 2005-5216 


\section{U.S. Department of the Interior \\ P. Lynn Scarlett, Acting Secretary}

\section{U.S. Geological Survey \\ P. Patrick Leahy, Acting Director}

\section{U.S. Geological Survey, Reston, Virginia: 2006}

For product and ordering information:

World Wide Web: http://www.usgs.gov/pubprod

Telephone: 1-888-ASK-USGS

For more information on the USGS--the Federal source for science about the Earth, its natural and living resources, natural hazards, and the environment:

World Wide Web: http://www.usgs.gov

Telephone: 1-888-ASK-USGS

Any use of trade, product, or firm names is for descriptive purposes only and does not imply endorsement by the U.S. Government.

Although this report is in the public domain, permission must be secured from the individual copyright owners to reproduce any copyrighted materials contained within this report.

Suggested citation:

Parrett, Charles, 2006, Synthesis of monthly and annual streamflow records (water years 1950-2003) for Big Sandy, Clear, Peoples, and Beaver Creeks in the Milk River Basin, Montana: U.S. Geological Survey Scientific Investigations Report 2005-5216, 23 p. 


\section{Contents}

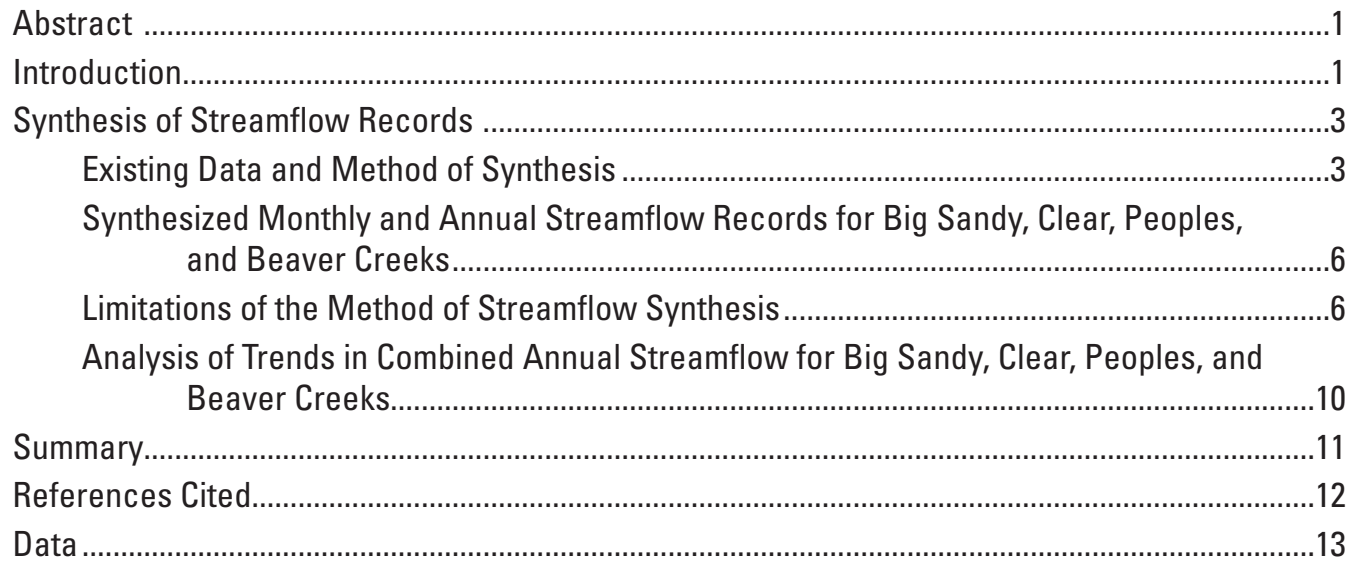

\section{Figures}

1. Map showing location of study area, Milk River and tributary streamflow-gaging stations for which records were synthesized and streamflow-gaging stations used for record synthesis, Milk River basin of Montana, Alberta, and Saskatchewan.............2

2-8. Graphs showing:

2. Synthesized annual streamflow for various exceedance probabilities for Big Sandy, Clear, Peoples, and Beaver Creeks, Milk River basin, Montana, water years 1950-2003.

3. Combined synthesized annual streamflow for various exceedance probabilities for Big Sandy, Clear, Peoples, and Beaver Creeks, Milk River basin, Montana, water years 1950-2003.

4. Variation of combined synthesized monthly streamflow for Big Sandy, Clear, Peoples, and Beaver Creeks, Milk River Basin, Montana, water years 1950-2003..........8

5. Variation in monthly streamflow for Big Dry Creek near Van Norman, Montana, for water years 1950-2003.

6. Variation in daily and monthly streamflow in May 1999 for Big Sandy, Clear, Peoples, and Beaver Creeks, Milk River basin, Montana.

7. Analysis of trend in combined synthesized annual streamflow for Big Sandy, Clear, Peoples, and Beaver Creeks, Milk River basin, Montana, water years 1950-2003.

8. Analysis of trend in combined synthesized annual streamflow for Big Sandy, Clear, Peoples, and Beaver Creeks, Milk River basin, Montana, water years 1956-2003. 


\section{Tables}

1. Data for selected streamflow-gaging stations in the Milk River basin and streamflow-gaging stations used as base stations for record synthesis, Montana.

2. Summary of selected information for synthesis of flow records for Big Sandy, Clear, Peoples, and Beaver Creeks, Milk River basin, Montana, water years 1950-2003.

3. Recorded and estimated monthly and annual streamflow for Big Sandy Creek, Milk River basin, Montana, water years 1950-2003.

4. Recorded and estimated monthly and annual streamflow for Clear Creek, Milk River basin, Montana, water years 1950-2003.

5. Recorded and estimated monthly and annual streamflow for Peoples Creek, Milk River basin, Montana, water years 1950-2003.

6. Recorded and estimated monthly and annual streamflow for Beaver Creek, Milk River basin, Montana, water years 1950-2003.

7. Combined recorded and estimated monthly and annual streamflows for Big Sandy, Clear, Peoples, and Beaver Creeks, Milk River basin, Montana, water years 1950-2003

\section{Conversion Factors and Datum}

\begin{tabular}{lcl}
\hline Multiply & By & To obtain \\
\hline acre & 4,047 & square meter $\left(\mathrm{m}^{2}\right)$ \\
acre & 0.4047 & hectare $(\mathrm{ha})$ \\
acre-foot (acre-ft) & 1,233 & cubic meter $\left(\mathrm{m}^{3}\right)$ \\
acre-foot (acre-ft) & 0.001233 & cubic hectometer $\left(\mathrm{hm}^{3}\right)$ \\
acre-foot per month (acre-ft/mon) & 0.001233 & cubic hectometer per month $(\mathrm{hm} / \mathrm{mon})$ \\
acre-foot per year (acre-ft/yr) & 0.001233 & cubic hectometer per year $\left(\mathrm{hm}^{3} / \mathrm{yr}\right)$ \\
foot $(\mathrm{ft})$ & 0.3048 & meter $(\mathrm{m})$ \\
square mile $\left(\mathrm{mi}^{2}\right)$ & 259.0 & hectare $($ ha) \\
square mile $\left(\mathrm{mi}^{2}\right)$ & 2.590 & square kilometer $\left(\mathrm{km}^{2}\right)$ \\
\hline
\end{tabular}

Horizontal coordinate information is referenced to the North American Datum of 1927 (NAD 27).

Water year refers to the 12 month period beginning October 1 and ending September 30 .

\section{Acronyms}

IJC International Joint Commission

SRSP Streamflow-Record Synthesis Program

USGS U.S. Geological Survey 


\title{
Synthesis of Monthly and Annual Streamflow Records (Water Years 1950-2003) for Big Sandy, Clear, Peoples, and Beaver Creeks in the Milk River Basin, Montana
}

\author{
By Charles Parrett
}

\section{Abstract}

To address concerns expressed by the State of Montana about the apportionment of water in the St. Mary and Milk River basins between Canada and the United States, the International Joint Commission requested information from the United States government about water that originates in the United States but does not cross the border into Canada. In response to this request, the U.S. Geological Survey synthesized monthly and annual streamflow records for Big Sandy, Clear, Peoples, and Beaver Creeks, all of which are in the Milk River basin in Montana, for water years 1950-2003.

This report presents the synthesized values of monthly and annual streamflow for Big Sandy, Clear, Peoples, and Beaver Creeks in Montana. Synthesized values were derived from recorded and estimated streamflows. Statistics, including long-term medians and averages and flows for various exceedance probabilities, were computed from the synthesized data.

Beaver Creek had the largest median annual discharge (19,490 acre-feet), and Clear Creek had the smallest median annual discharge (6,680 acre-feet). Big Sandy Creek, the stream with the largest drainage area, had the second smallest median annual discharge (9,640 acre-feet), whereas Peoples Creek, the stream with the second smallest drainage area, had the second largest median annual discharge (11,700 acre-feet). The combined median annual discharge for the four streams was 45,400 acre-feet. The largest combined median monthly discharge for the four creeks was 6,930 acre-feet in March, and the smallest combined median monthly discharge was 48 acre-feet in January. The combined median monthly values were substantially smaller than the average monthly values.

Overall, synthesized flow records for the four creeks are considered to be reasonable given the prevailing climatic conditions in the region during the 1950-2003 base period. Individual estimates of monthly streamflow may have large errors, however.

Linear regression was used to relate logarithms of combined annual streamflow to water years 1950-2003. The results of the regression analysis indicated a significant downward trend (regression line slope was -0.00977) for combined annual streamflow. A regression analysis using data from
1956-2003 indicated a slight, but not significant, downward trend for combined annual streamflow.

\section{Introduction}

Water in the Milk and St. Mary Rivers in northern Montana and southern Canada is apportioned between the United States and Canada in accordance with the Boundary Waters Treaty of 1909. The International Joint Commission (IJC) Order of 1921 further clarified how the water of the two rivers would be apportioned. The Order provides for the measurement of water that flows across the boundary but does not call for the measurement of water that originates in one country but does not cross the boundary. Increasing use of water from the Milk River and recent drought conditions have raised concerns by the State of Montana about how apportionment under the Treaty is being implemented. In 2003, the State of Montana formally expressed concerns to the IJC about the apportionment. To assist it in carrying out its responsibilities under the Treaty, the IJC asked the Canadian and United States governments to provide it with an accounting of water in the two basins that originates in one country but does not cross the boundary. The U.S. Geological Survey (USGS) is assisting the United States government in responding to the request by providing estimates of the amount of streamflow in selected tributaries of the Milk River that originate in the United States and do not cross the international boundary. Specifically, the USGS estimated monthly and annual streamflow for Big Sandy, Clear, Peoples, and Beaver Creeks (fig. 1) for water years 1950-2003.

Big Sandy Creek has the largest drainage area $\left(1,805 \mathrm{mi}^{2}\right)$ of the four creeks. Sage Creek, the largest of the Big Sandy Creek tributaries, drains a small portion of the Sweet Grass Hills and flows through plains for most of its length on the western side of the Big Sandy Creek basin. Big Sandy Creek drains a small portion of the Bears Paw Mountains before flowing for most of its length through plains on the east side of the basin. Big Sandy Creek arises on and flows through the Rocky Boys Indian Reservation. 


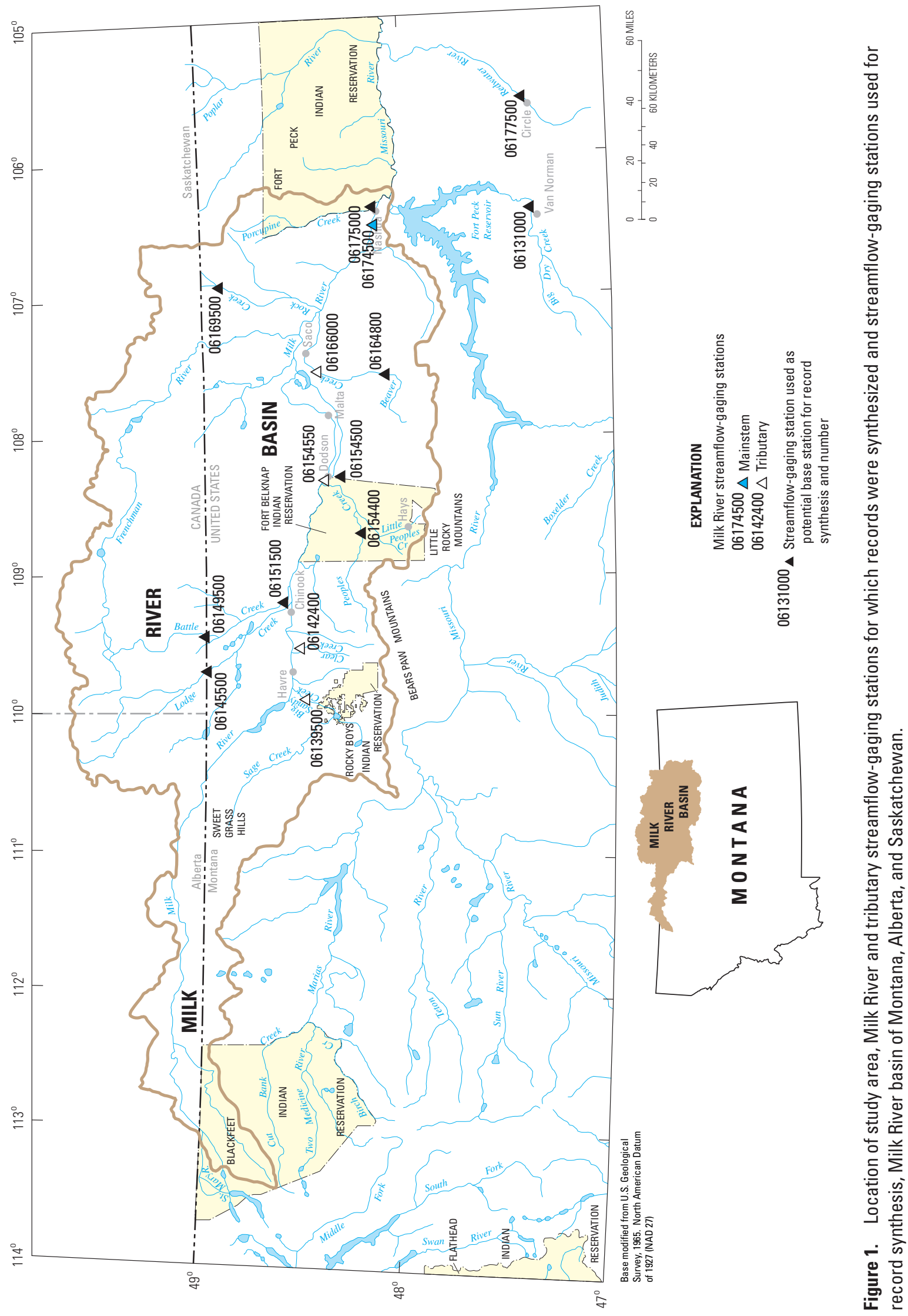


Clear Creek also drains a small portion of the Bears Paw Mountains before flowing almost all of its length through plains east of the Big Sandy Creek basin. Clear Creek, which has the smallest drainage area of the four creeks $\left(135 \mathrm{mi}^{2}\right)$, does not drain any land on Indian reservations.

Peoples Creek also drains a small portion of the Bears Paw Mountains on the western edge of the basin. Little Peoples Creek, a major tributary, drains a portion of the Little Rocky Mountains near the southern boundary of the basin. Peoples Creek has a drainage area of $675 \mathrm{mi}^{2}$ and flows through plains on the Fort Belknap Indian Reservation for much of its length.

Beaver Creek drains a small portion of the Little Rocky Mountains near the southern edge of the basin. Beaver Creek and its tributaries flow through plains for most of their length. Beaver Creek drains about 1,200 $\mathrm{mi}^{2}$, none of which is on Indian reservations.

All four creeks have some irrigation use, although the use is sporadic and relatively minor. Streamflows on all four creeks generally are intermittent and undependable for sustained use.

This report presents synthesized monthly and annual streamflow records (in acre-ft/mon and acre-ft/yr). Recorded monthly and annual streamflow data were used when available (table 1) for Big Sandy, Clear, Peoples, and Beaver Creeks in Montana; monthly and annual streamflows for water years 1950-2003 were estimated only for intervals during which recorded streamflow data either did not exist or were incomplete. Statistics, including long-term medians and averages and flows for various exceedance probabilities, were computed from the synthesized records. The synthesized values of monthly and annual streamflow for all four creeks were combined for each water year and exceedance probabilities for the combined annual streamflow also were determined. In addition, the combined annual streamflow values were analyzed for systematic increases or decreases.

\section{Synthesis of Streamflow Records}

\section{Existing Data and Method of Synthesis}

Big Sandy, Clear, Peoples, and Beaver Creeks all have been gaged, at least on a seasonal basis, for several years by the USGS. Peoples Creek and Beaver Creek have had streamflow-gaging stations at more than one location. The streamflow-gaging stations farthest downstream on Peoples Creek (station 06154550) and Beaver Creek (station 06166000) were used for estimation of long-term flow for those streams. The locations of these streams and gaging stations are shown on figure 1 , and the station location, drainage area, and periods of streamflow record at the stations are indicated on table 1 .

As indicated by table 1, Big Sandy, Clear, Peoples, and Beaver Creeks all have different periods of record, and two of the four streams have flow record only on a seasonal basis, beginning either in April, May, or June and continuing through September. Accordingly, a streamflow-record synthesis program (SRSP) developed by Alley and Burns (1983) was used to synthesize streamflow record for those months with missing streamflow data for all four sites. The SRSP is based on correlation of recorded monthly flows at the site requiring synthesized monthly flow data with concurrent monthly flows at a nearby streamflow-gaging station with similar streamflow characteristics. Streamflow-gaging stations (base stations) located in northeastern Montana that are considered to have streamflow characteristics similar to those for Big Sandy, Clear, Peoples, and Beaver Creeks are shown in figure 1. The selected base period for synthesis of the streamflow record represents a long-term period during which both droughts and high runoff have occurred in northeastern Montana and during which several streams in the general area have had nearly complete monthly flow record available for correlation analysis. Although all streams shown in table 1 have some irrigation water use, the use generally is small. Streamflows during times of irrigation use are reduced, but streamflows may be increased somewhat later in the season from irrigation return flow. Water use from and subsequent return flow to these streams probably has not changed substantially during the 1950-2003 base period, except in response to the variable climatic and runoff conditions. The effects of any irrigation water use were not considered separately as part of this study.

The SRSP selects the best base stations from all those available in a region to estimate missing streamflow data for sites where the record was synthesized. Thus, several different base stations might be used for making estimates for a single site. The criterion for selection of the best base station is to use the station with a streamflow record that results in the smallest standard error of prediction for that month. Only stations with streamflow record for a particular month and year were used to estimate missing streamflow data for other sites for that same month and year. Previously estimated monthly flows were not used to estimate missing streamflow data for this report. Each of the four sites requiring synthesized flow records also was used as a potential base station for making estimates for the other three sites. For example, flow record for Peoples Creek may have been used to estimate a month of missing flow data for Clear Creek.

In addition to the capability of using more than one base station to estimate missing monthly flow data, the SRSP also has the option of using a cyclic or noncyclic equation to estimate missing monthly flow data. If the cyclic option is selected, an equation is computed for each month using only concurrent flow data for that month. If the noncyclic option is selected, a single equation is computed for all months using all concurrent monthly flow data. For example, for 2 stations with 20 years of concurrent monthly flow record, the cyclic option would result in 12 monthly estimation equations, each based on 20 concurrent flows. The noncyclic option for the same 2 sites would result in 1 estimation equation based on 240 concurrent monthly flows. The criterion of having the smallest standard error of prediction also was used to select 
the cyclic or noncyclic option for each estimate. Streamflow records from base stations were not used to synthesize record for another station unless records of the two stations had at least 20 concurrent monthly streamflow values.

The correlation procedure used to estimate missing flow data for all sites was the Maintenance of Variance Extension, Type 1 (MOVE.1) procedure described by Hirsch (1982). This procedure is analogous to Ordinary Least Squares regression but it has the important advantage that it produces a synthesized flow record with a variance similar to that of the short flow record.
Data for base stations that were used to synthesize flow record for each of the four Milk River tributary stations and a measure of the overall reliability of the estimated monthly flows (average standard error of prediction) calculated by the SRSP are shown in table 2. For clarity, only the three base stations that were most often used to estimate missing monthly flows are presented in table 2 . Thus, data from the three base stations most often used for estimation of monthly flows for Big Sandy Creek (station 06139500) were used to make 463 out of 477 monthly flow estimates, the three most often used base stations for Clear Creek (station 06142400) were used to

Table 1. Data for selected streamflow-gaging stations in the Milk River basin and streamflow-gaging stations used as base stations for record synthesis, Montana.

[All sites in Montana except as indicated]

\begin{tabular}{|c|c|c|c|c|c|}
\hline $\begin{array}{l}\text { Station } \\
\text { number } \\
\text { (fig. 1) }\end{array}$ & Station name & Latitude & Longitude & $\begin{array}{l}\text { Drainage area, } \\
\text { square miles }\end{array}$ & Period of monthly flow record \\
\hline \multicolumn{6}{|c|}{ Sites for which streamflow record was synthesized ${ }^{1}$} \\
\hline 06139500 & Big Sandy Creek near Havre & $48^{\circ} 31 ’ 36^{\prime \prime}$ & $109^{\circ} 50^{\prime} 27^{\prime \prime}$ & 1,805 & $\begin{array}{l}\text { 2/1946-9/1953; 10/1984; 5/1984- } \\
\quad \text { 9/2003 (seasonal) }\end{array}$ \\
\hline 06142400 & Clear Creek near Chinook & $48^{\circ} 34^{\prime} 44^{\prime \prime}$ & $109^{\circ} 23^{\prime} 26^{\prime \prime}$ & 135 & $6 / 1984-9 / 2003$ (seasonal) \\
\hline 06166000 & $\begin{array}{l}\text { Beaver Creek below Guston Coulee, } \\
\text { near Saco }\end{array}$ & $48^{\circ} 21 ’ 24^{\prime \prime}$ & $107^{\circ} 34^{\prime} 56^{\prime \prime}$ & 1,208 & $\begin{array}{l}\text { 4/1920-9/1921; 4/1981-9/2003 } \\
\quad \text { (seasonal) }\end{array}$ \\
\hline \multicolumn{6}{|c|}{ Sites for which streamflow record was used for record synthesis } \\
\hline 06131000 & Big Dry Creek near Van Norman & $47^{\circ} 20^{\prime} 58^{\prime \prime}$ & $106^{\circ} 21^{\prime} 26^{\prime \prime}$ & 2,554 & $10 / 1939-9 / 1947 ; 4 / 1949-9 / 2003$ \\
\hline 06151500 & Battle Creek near Chinook & $48^{\circ} 38^{\prime} 58^{\prime \prime}$ & $109^{\circ} 13 ’ 54 ”$ & 1,623 & $\begin{array}{l}\text { 4/1905-9/1921 (seasonal); 5/1944; } \\
\text { 6/1984-9/2003 (seasonal) }\end{array}$ \\
\hline 06154400 & Peoples Creek near Hays & $48^{\circ} 13^{\prime} 25^{\prime \prime}$ & $108^{\circ} 42^{\prime} 48^{\prime \prime}$ & 220 & $12 / 1966-9 / 2003$ \\
\hline 06154500 & Peoples Creek near Dodson & $48^{\circ} 20^{\prime} 34^{\prime \prime}$ & $108^{\circ} 21 ’ 32 ”$ & 670 & $\begin{array}{l}\text { 4/1918-9/1921 (seasonal); 10/1950- } \\
\text { 12/1950; 6/1951-9/1973; 10/1980- } \\
\text { 12/1980; 10/1982-9/1988 }\end{array}$ \\
\hline 06164800 & $\begin{array}{l}\text { Beaver Creek above Dix Creek, near } \\
\text { Malta }\end{array}$ & $48^{\circ} 05^{\prime} 20^{\prime \prime}$ & $107^{\circ} 33^{\prime} 18^{\prime \prime}$ & 929 & 10/1966-9/1969; 10/1976-9/1982 \\
\hline
\end{tabular}

${ }^{1}$ Records from these stations also were used for record synthesis. 
make 483 out of 521 monthly estimates, the three most often used base stations for Peoples Creek (station 06154550) were used to make 105 out of 114 monthly flow estimates, and the three most often used base stations for Beaver Creek (station 06166000) were used to make 409 out of 483 monthly estimates. Table 2 indicates that Clear Creek required the most estimates of monthly flow (521), whereas Peoples Creek required the fewest (114).

Table 2 also indicates that the average standard error of prediction for monthly streamflow ranged from 571 percent for Peoples Creek to 5,678 percent for Beaver Creek. These large values are, in part, due to the difficulty in computing per- centage errors when stations have numerous values of monthly streamflow that are zero or near-zero. Logarithms of streamflow are used within the program for calculation, and because the logarithm of zero is undefined, the program adds 0.01 to zero values of streamflow. Consequently, differences between small values of estimated and true streamflow (errors) can be very large when expressed as percentages, particularly when the estimated value is larger than the true value. For example, if an estimated monthly streamflow is 1 when the true streamflow is zero (assumed value of 0.01 for use in the program), the error ( 1 minus 0.01 , or 0.99 ) is 9,900 percent of the true value. On the other hand, if an estimated monthly streamflow

Table 2. Summary of selected information for synthesis of flow records for Big Sandy, Clear, Peoples, and Beaver Creeks, Milk River basin, Montana, water years 1950-2003.

[All sites in Montana; others, all other base stations used for record synthesis]

\begin{tabular}{|c|c|c|c|c|}
\hline \multicolumn{2}{|c|}{$\begin{array}{c}\text { Number of monthly streamflows, } \\
\text { water years } 1950-2003\end{array}$} & \multirow{2}{*}{$\begin{array}{l}\text { Base stations } \\
\text { used for record } \\
\text { synthesis }\end{array}$} & \multirow{2}{*}{$\begin{array}{l}\text { Number of monthly } \\
\text { streamflow estimates } \\
\text { from base station }\end{array}$} & \multirow{2}{*}{$\begin{array}{c}\text { Standard error } \\
\text { of prediction, } \\
\text { in percent }^{1}\end{array}$} \\
\hline Recorded & Estimated & & & \\
\hline \multicolumn{5}{|c|}{06139500 Big Sandy Creek near Havre } \\
\hline \multirow[t]{5}{*}{171} & 477 & 06154400 & 255 & \\
\hline & & 06154550 & 199 & \\
\hline & & 06149500 & 9 & \\
\hline & & Others & 14 & \\
\hline & & Total & 477 & 1,183 \\
\hline \multicolumn{5}{|c|}{06142400 Clear Creek near Chinook } \\
\hline \multirow[t]{5}{*}{127} & 521 & 06154400 & 283 & \\
\hline & & 06154500 & 188 & \\
\hline & & 06169500 & 12 & \\
\hline & & Others & 38 & \\
\hline & & Total & 521 & 680 \\
\hline \multicolumn{5}{|c|}{06154550 Peoples Creek below Kuhr Coulee, near Dodson } \\
\hline \multirow[t]{5}{*}{534} & 114 & 06154400 & 85 & \\
\hline & & 06139500 & 12 & \\
\hline & & 06169500 & 8 & \\
\hline & & Others & 9 & \\
\hline & & Total & 114 & 571 \\
\hline \multicolumn{5}{|c|}{06166000 Beaver Creek below Guston Coulee, near Saco } \\
\hline \multirow[t]{5}{*}{165} & 483 & 06154500 & 232 & \\
\hline & & 06154400 & 120 & \\
\hline & & 06145500 & 57 & \\
\hline & & Others & 74 & \\
\hline & & Total & 483 & 5,678 \\
\hline
\end{tabular}

${ }^{1}$ Value is average for all monthly flow estimates for each site where streamflow record was synthesized. 
is zero (assumed value of 0.01 for use in the program) when the true streamflow is 1 , the error $(0.99)$ is only 99 percent of the true value. Thus, the average error for the two estimates is 5,000 percent, even though the average magnitude of the error is zero. On this basis, the large average standard errors of prediction (which are analogous to the percentage errors just described) for the four Milk River tributary sites are believed to have a relatively small effect on the synthesized long-term streamflow records.

\section{Synthesized Monthly and Annual Streamflow Records for Big Sandy, Clear, Peoples, and Beaver Creeks}

The synthesized monthly values of streamflow for the four Milk River tributary streams for water years 1950-2003 are shown in tables 3-6 (at the back of the report). In addition, synthesized monthly flows were summed for each water year to provide estimates of annual streamflow. Similarly, the synthesized monthly and annual values of streamflow for all four Milk River tributary streams were combined (table 7, at the back of the report) to provide monthly and annual totals for these tributaries for each water year. The values for annual streamflow for each site and for the combined total were statistically summarized, and the long-term median and average flows and flows for various exceedance probabilities are shown in figures 2 and 3. Statistics also were computed for the long-term combined monthly streamflows. The long-term flows with an exceedance probability of 0.10 and median and average flows are shown in the form of bar charts in figure 4 .

Data shown in the tables and figures indicate that all streams had many months during the 1950-2003 water years of zero or near-zero flows, especially in fall and winter. All streams generally had their largest values of monthly flow in either March or April, coinciding with spring snowmelt; however, all streams also had several large values of monthly flow in summer resulting from large rainstorms. The long-term median monthly flow for all streams was substantially less than the average monthly flow. The large differences between median and average values are typical of streams with highly variable monthly flow from year to year (fig. 4). For example, Big Sandy Creek had only 22 of 54 values of October monthly flow greater than zero (table 3). Nevertheless, the long-term monthly average flow for October was 490 acre-ft compared to a median value of zero. Estimates of long-term median monthly or annual flow are likely to be more reliable than estimates of long-term average monthly or annual flow. Averages are more sensitive to the effects of outliers than are medians and are thus more likely to be affected by individual monthly values that may be outliers simply because of large estimation errors.

Beaver Creek had the largest median annual flow $(19,490$ acre-ft), and Clear Creek had the smallest median annual flow (6,680 acre-ft). Big Sandy Creek, the stream with the largest drainage area, had the second smallest median annual flow (9,640 acre-ft), whereas Peoples Creek, the stream with the second smallest drainage area, had the second largest median annual flow (11,700 acre-ft). The somewhat larger flow from Peoples Creek relative to flow from Big Sandy Creek may be partly attributable to somewhat greater precipitation and runoff from headwater areas of Peoples Creek than from headwater areas of Big Sandy Creek.

The combined median annual flow for the four streams was 45,400 acre-ft (table 7). For comparison, the median annual flow for the USGS streamflow-gaging station Milk River at Nashua (station 06174500) for the 1950-2003 period was 366,000 acre-ft. The largest combined median monthly flow for the four creeks was 6,930 acre-ft in March, and the smallest combined median monthly flow was 48 acre-ft in January. The combined median monthly values were substantially smaller than the average monthly values.

\section{Limitations of the Method of Streamflow Synthesis}

As previously described, streamflows in northeastern Montana are highly variable, both temporally and spatially. For example, flow for a given month in a particular stream may vary from zero in one year to several thousand acre-ft in the next year. This large temporal variability in streamflow is illustrated graphically in figure 5 . The bars in figure 5 show the maximum, median, and minimum values of recorded monthly streamflow at Big Dry Creek near Van Norman, Montana (station 06131000), a base station used for synthesis of monthly flow records, for the 1950-2003 base period. As indicated on figure 5, the minimum flow for most months is zero, whereas the maximum flow for those same months ranges from almost 1,000 acre-ft to more than 55,000 acre-ft. Likewise, flow for a given month might be several thousand acre- $\mathrm{ft}$ at one site subject to a large synoptic storm, but nearly zero at a nearby site outside the path of the storm. Figure 6 graphically illustrates the large spatial variability in recorded daily and monthly streamflow at Big Sandy, Clear, Peoples, and Beaver Creeks during May 1999. Figure 6 indicates that all four streams had about the same flow at the beginning and end of May, but Beaver Creek had much larger flow from storm runoff in the middle of May. The resultant total flow for May 1999 was much larger for Beaver Creek than any of the other Milk River tributary streams. Individual estimates of monthly flow at any of the Milk River tributary sites may thus have large errors and need to be used with caution. Estimates of annual flow for any year or long-term median or average monthly or annual flow are likely to be more reliable than individual monthly estimates, because adding the individual monthly flows tends to dampen individual errors. Overall, the synthesized flow records, which comprise both recorded and estimated monthly data, for Big Sandy, Clear, Peoples, and Beaver Creek are believed to be reasonable and plausible, given the climatic conditions of the region during the 19502003 base period. 

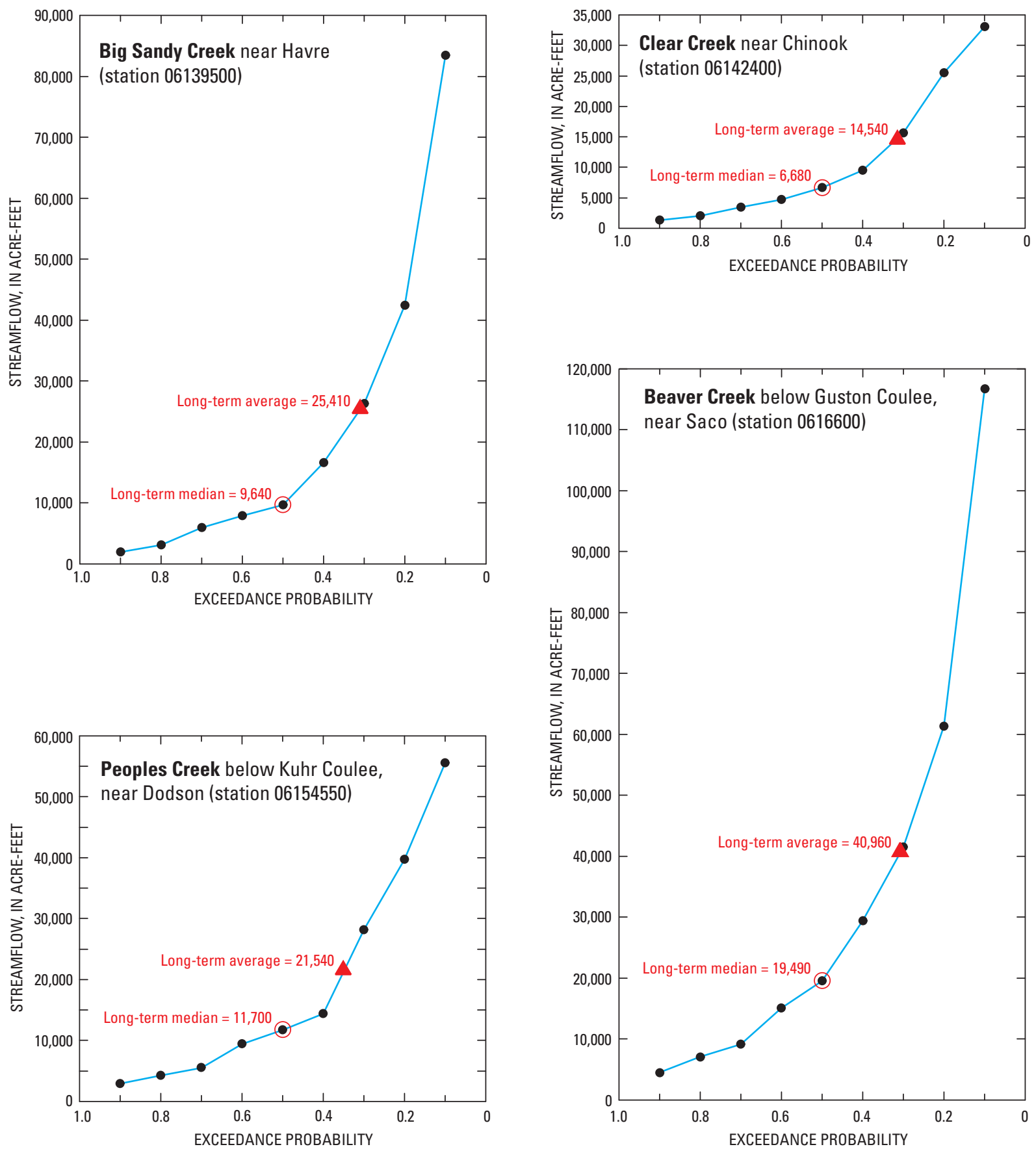

Figure 2. Synthesized annual streamflow for various exceedance probabilities for Big Sandy, Clear, Peoples, and Beaver Creeks, Milk River basin, Montana, water years 1950-2003. 


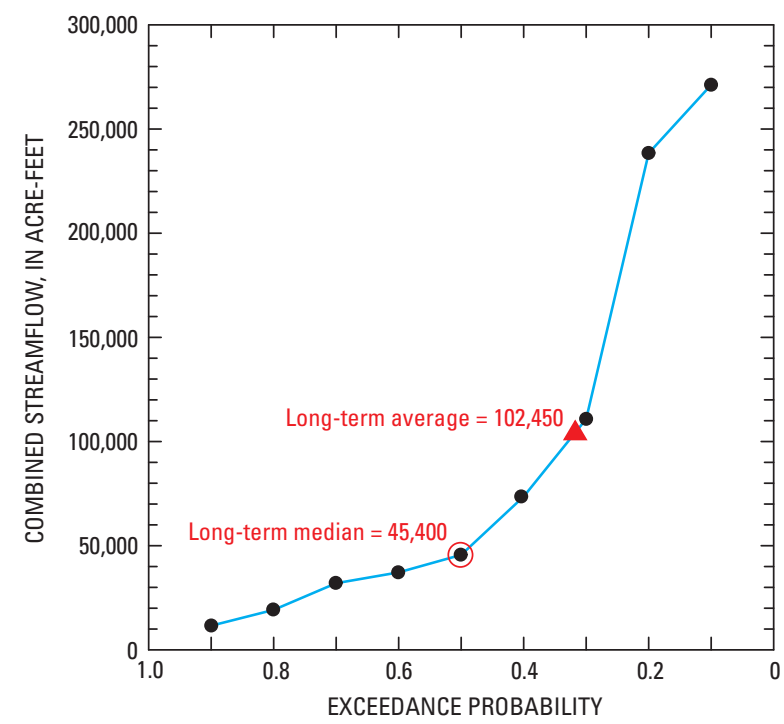

Figure 3. Combined synthesized annual streamflow for various exceedance probabilities for Big Sandy, Clear, Peoples, and Beaver Creeks, Milk River basin, Montana, water years 1950-2003.

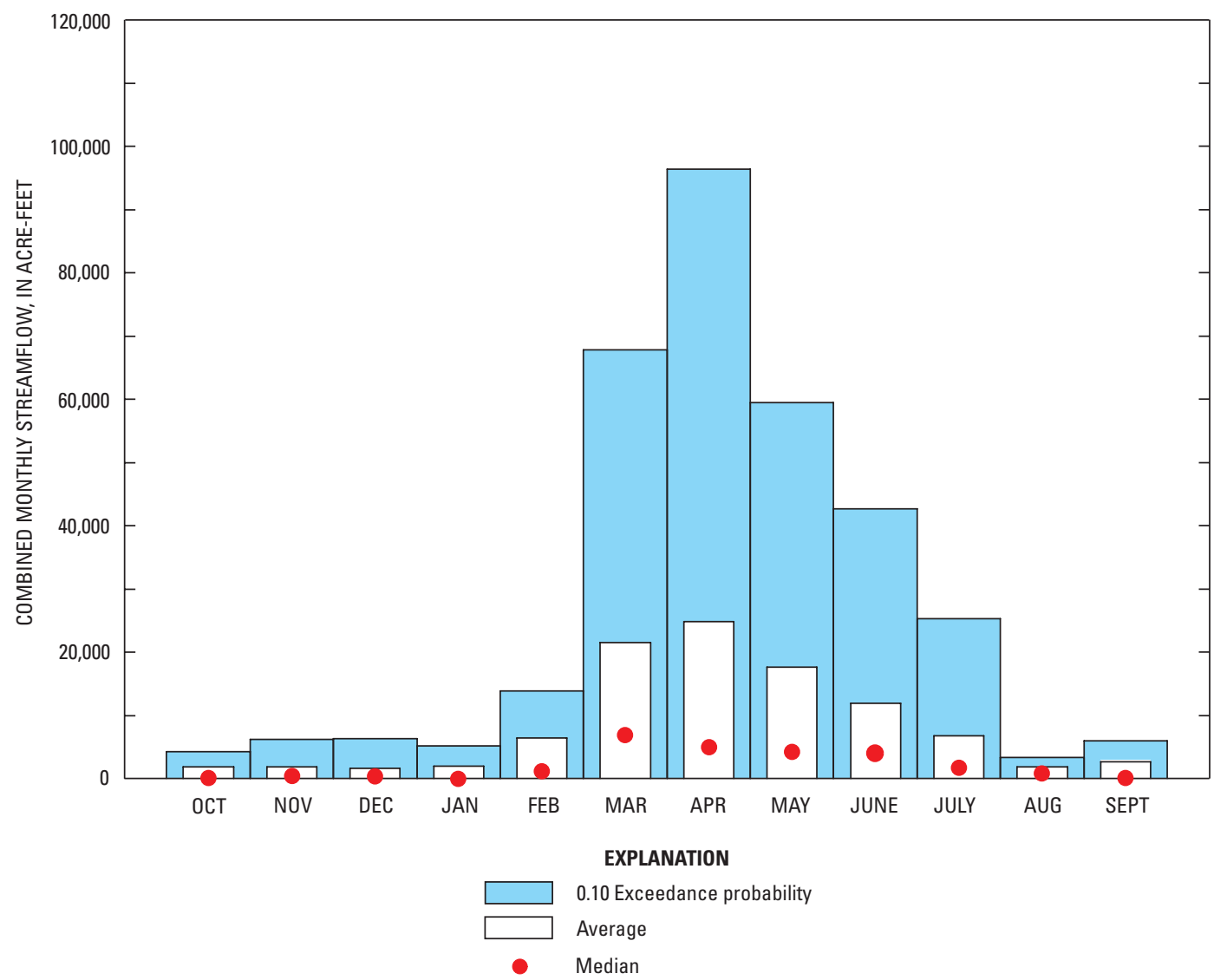

Figure 4. Variation of combined synthesized monthly streamflow for Big Sandy, Clear, Peoples, and Beaver Creeks, Milk River Basin, Montana, water years 1950-2003. 


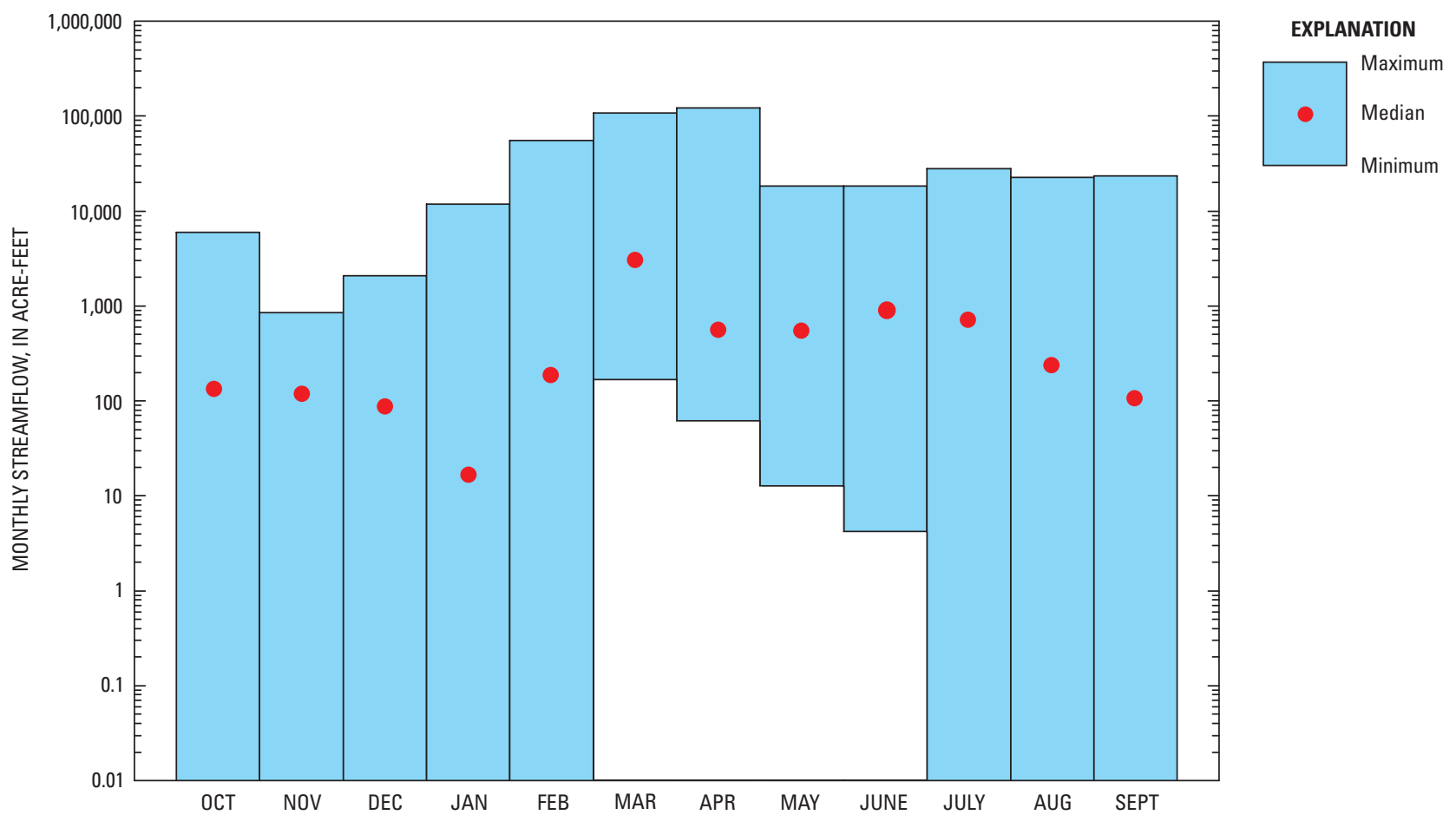

Figure 5. Variation in monthly streamflow for Big Dry Creek near Van Norman, Montana (station 06131000), for water years 1950-2003. Minimum values for October through February and July through September are zero.
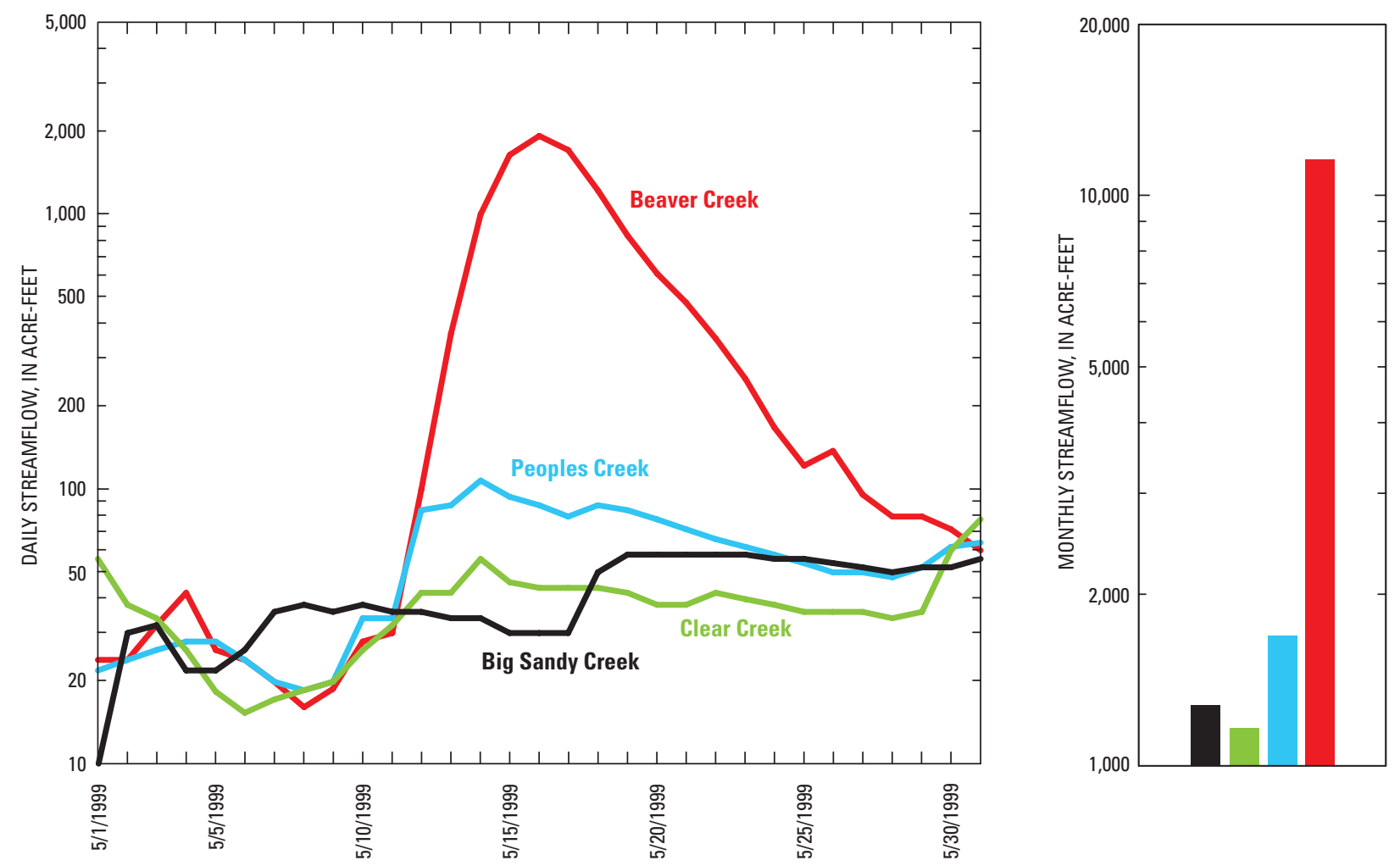

Figure 6. Variation in daily and monthly streamflow in May 1999 for Big Sandy, Clear, Peoples, and Beaver Creeks, Milk River basin, Montana. 


\section{Analysis of Trends in Combined Annual Streamflow for Big Sandy, Clear, Peoples, and Beaver Creeks}

Although the period of water years 1950-2003 is long enough to contain periods of both drought and high runoff, the recent drought condition in northeastern Montana has been especially persistent and might have biased the synthesized records of long-term streamflow. Accordingly, the synthesized record of combined annual streamflow was analyzed to determine whether a significant trend was evident during water years 1950-2003. Linear regression was used to relate logarithms of combined annual streamflow to water years 1950-2003. The slope of the regression line, if statistically significant, provides an indication of trend in combined annual streamflow. The results of the regression analysis indicated a downward trend (regression line slope is -0.00977) for combined annual streamflow (fig. 7). The $p$ value, or attained level of significance (Helsel and Hirsch, 1992), was 0.05, indicating that the trend is significant at the 95-percent confidence level ( $p$ value less than or equal to 0.05 ). The downward trend appears to be the result of persistent low-flow conditions over the last 4 years in combination with persistent highflow conditions during the early 1950s. To further test the effects of the high-flow conditions in the early 1950s on the trend of combined annual streamflow, the regression analysis was repeated for only water years 1956-2003. The slope of the regression line for this analysis (fig. 8) was still slightly downward (-0.00863), but the $p$ value was 0.15 , indicating that the downward trend is not significant. On this basis, the significant downward trend for combined annual streamflow for water years 1950-2003 can likely be largely attributed to the high flows during the early part of the period.

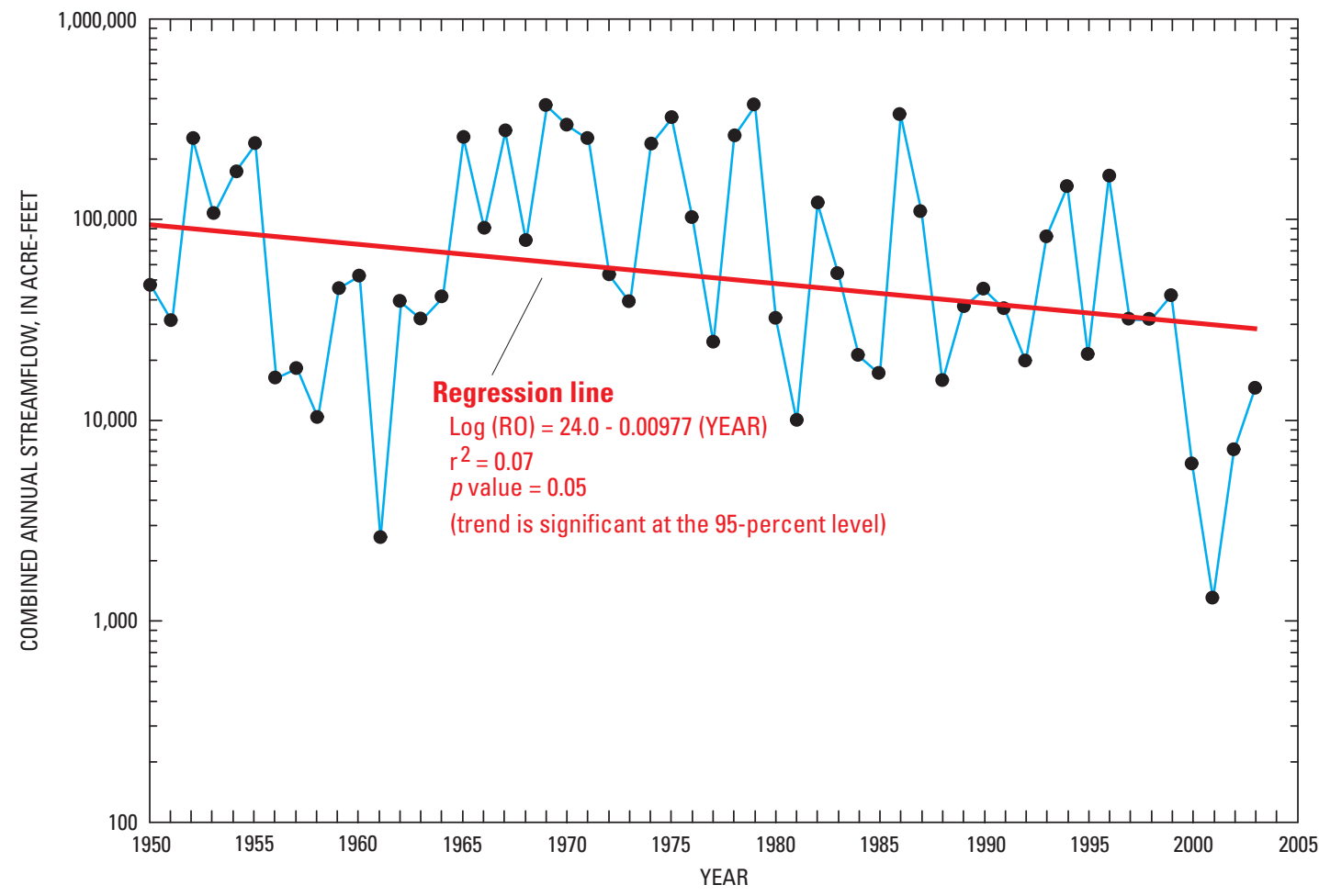

Figure 7. Analysis of trend in combined synthesized annual streamflow for Big Sandy, Clear, Peoples, and Beaver Creeks, Milk River basin, Montana, water years 1950-2003. 


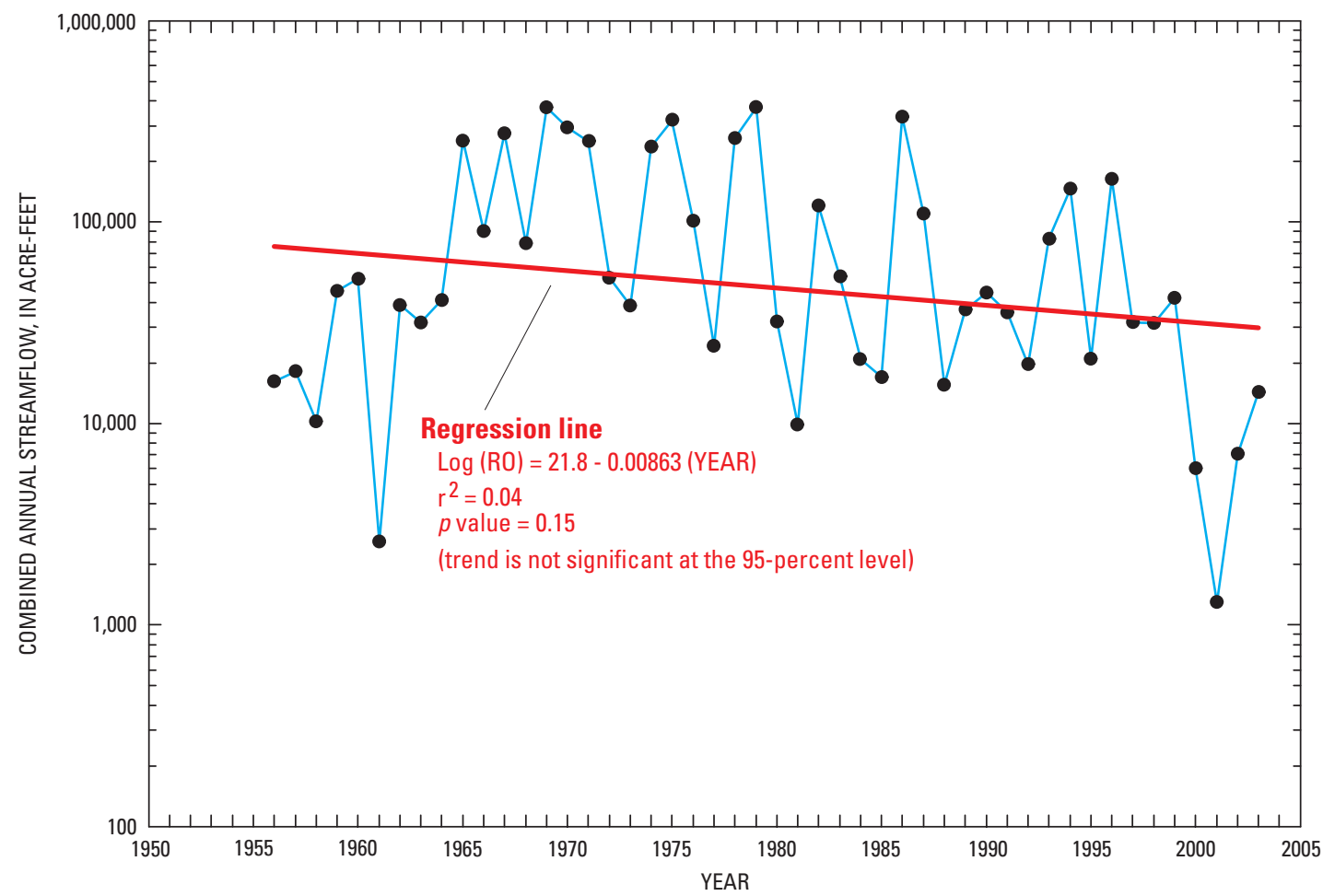

Figure 8. Analysis of trend in combined synthesized annual streamflow for Big Sandy, Clear, Peoples, and Beaver Creeks, Milk River basin, Montana, water years 1956-2003.

\section{Summary}

To address concerns expressed by the State of Montana about the apportionment of water in the St. Mary and Milk River basins between Canada and the United States, the International Joint Commission requested information from the United States government about water that originates in the United States but does not cross the border into Canada. In response to this request, the U.S. Geological Survey synthesized monthly and annual streamflow records for Big Sandy, Clear, Peoples, and Beaver Creeks, all of which are in the Milk River basin in Montana, for the period 1950-2003. Peoples Creek and Beaver Creek have had streamflow-gaging stations at more than one location. The streamflow-gaging stations farthest downstream on Peoples Creek (station 06154550) and Beaver Creek (station 06166000) were used for synthesis of recorded and estimated monthly and annual streamflow for those streams.

A streamflow-record synthesis program, based on correlation of recorded monthly flows at the site requiring monthly flow estimates with concurrent monthly flows at some nearby base station, was used to estimate missing months of streamflow during the 1950-2003 period. Only stations with streamflow record for a particular month and year were used to estimate missing streamflow data for other sites for that month and year; previously estimated monthly flows were not used to estimate any other missing monthly flows.

In addition to the capability of using more than one base station to estimate missing monthly flow record, the recordsynthesis program also has the option of using a cyclic or noncyclic equation to estimate monthly flow data. Streamflow records from base stations were not used to estimate missing record for another station unless records of the two stations had at least 20 concurrent monthly streamflow values.

Clear Creek required the most estimates of monthly flow (521), whereas Peoples Creek required the fewest (114). Average standard errors of prediction for the estimated monthly flows ranged from 571 to 5,678 percent. These large values are, in part, due to the difficulty in computing percentage errors when stations have a large number of zero or near-zero values of monthly streamflow.

The values for monthly and annual streamflow for each site and for the combined total flows for the four sites were statistically summarized, and the long-term median and average flows and flows for various exceedance probabilities were computed. Data show that all streams had many months during the 1950-2003 water years of zero or near-zero flows, especially in fall and winter. All streams generally had their largest values of monthly flow in either March or April, coinciding with spring snowmelt; however, all streams also had 
several large values of monthly flow in summer resulting from large rainstorms. The long-term median monthly flow for all streams was substantially less than the average monthly flow. The large differences between median and average values are typical of streams with highly variable monthly flow from year to year. For example, Big Sandy Creek had only 22 of 54 values of October monthly flow greater than zero. Nevertheless, the long-term monthly average flow for October was 490 acrefeet compared to a median value of zero.

Beaver Creek had the largest median annual flow (19,490 acre-ft), and Clear Creek had the smallest median annual flow (6,680 acre-ft). Big Sandy Creek, the stream with the largest drainage area, had the second smallest median annual flow (9,640 acre-ft), whereas Peoples Creek, the stream with the second smallest drainage area, had the second largest median annual flow (11,700 acre-ft). The somewhat larger flow from Peoples Creek relative to flow from Big Sandy Creek may be partly attributable to somewhat greater precipitation and runoff from headwater areas of Peoples Creek than from headwater areas of Big Sandy Creek.

The combined median annual flow for the four streams was 45,400 acre-ft. The largest combined monthly median flow for the four creeks was 6,930 acre-ft in March, and the smallest combined monthly median flow was 48 acre-ft in January. The combined monthly median values were substantially smaller than the monthly average values.

Overall, synthesized flow records for the four Milk River tributary streams are considered to be reasonable given the climatic conditions in the region during the 1950-2003 base period. Individual monthly estimates may have large errors, however, and need to be used with caution.

Linear regression was used to relate logarithms of combined annual streamflow to water years 1950-2003. The results of the regression analysis indicated a slight downward trend (regression line slope $=-0.00977$ ) for combined annual streamflow. The $p$ value, or attained level of significance, was 0.05 , indicating that the trend is significant at the 95-percent confidence level ( $p$ value less than or equal to 0.05 ). The regression analysis was repeated for water years 1956-2003, and the slight downward trend (regression line slope $=$ $-0.00863)$ was determined to be not significant $(p$ value $=$ $0.15)$. On this basis, the significant downward trend for combined annual streamflow for water years 1950-2003 can likely be largely attributed to the high flows during the early part of the period.

\section{References Cited}

Alley, W.M., and Burns, A.W., 1983, Mixed-station extension of monthly streamflow records: Journal of Hydraulic Engineering, v. 109 , no. 10 , p. 1272-1284.

Helsel, D.R., and Hirsch, R.M., 2002, Statistical methods in water resources: U.S. Geological Survey Techniques of Water-Resources Investigations Reports book 4, chap. A3. [Available online at http://pubs.usgs.gov/twri/twri4a3/].

Hirsch, R.M., 1982, A comparison of four streamflow-record extension techniques: Water Resources Research, v. 18, no. 4, p. 1081-1088. 
Data 


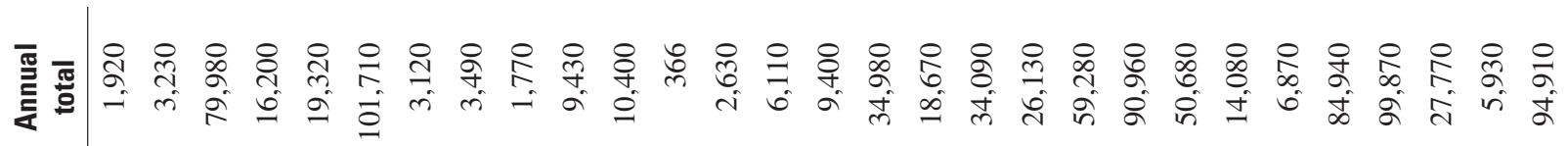

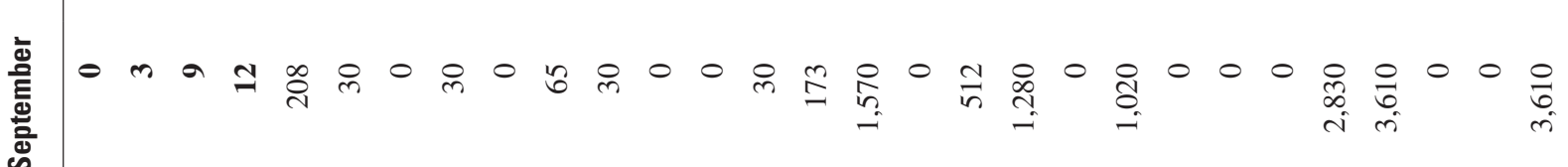

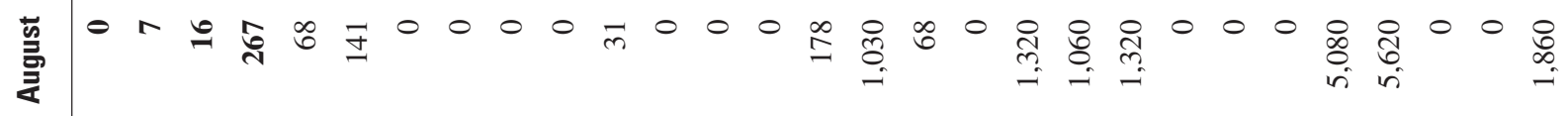

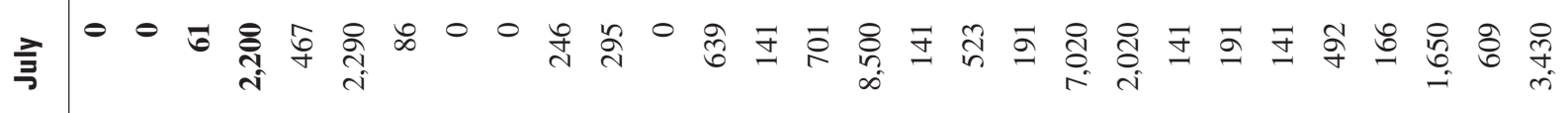

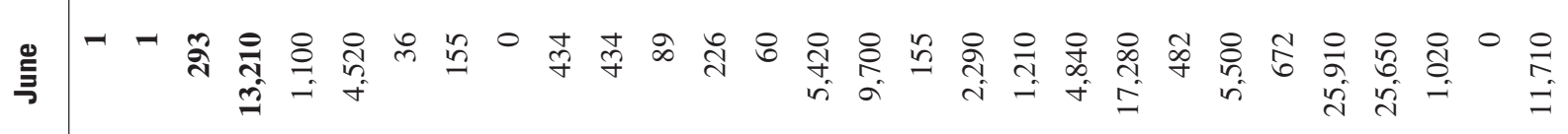

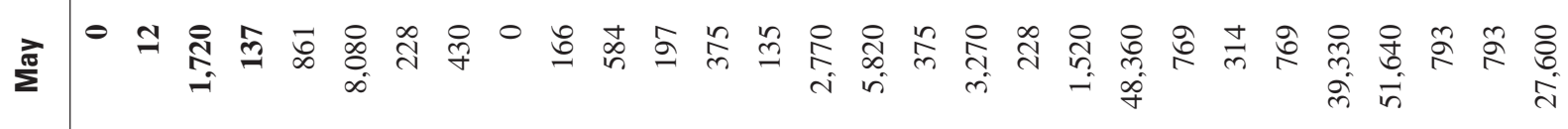

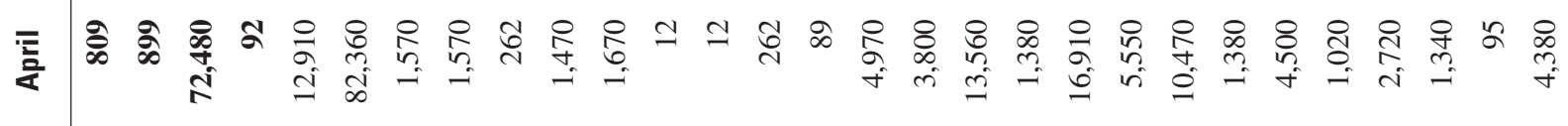

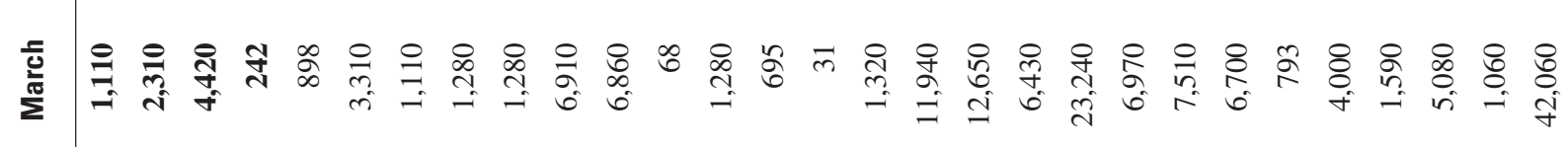

$$
\begin{aligned}
& \text { 焉 } \\
& \text { 焉 } \\
& \text { 焉 }
\end{aligned}
$$

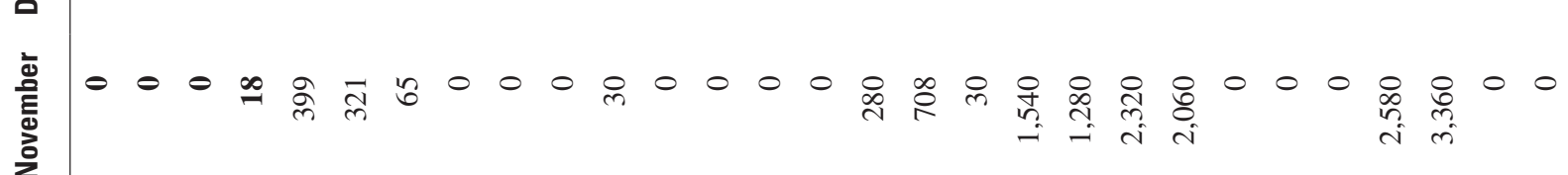

$$
\begin{aligned}
& \text { 兽 }
\end{aligned}
$$

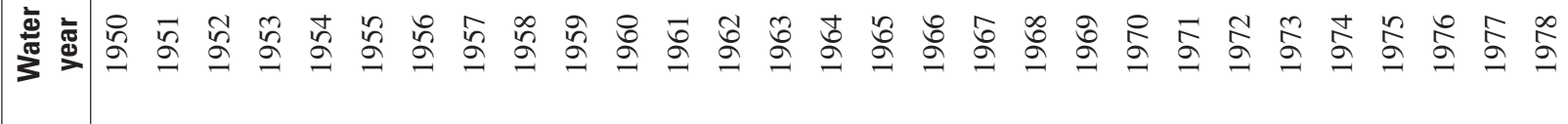




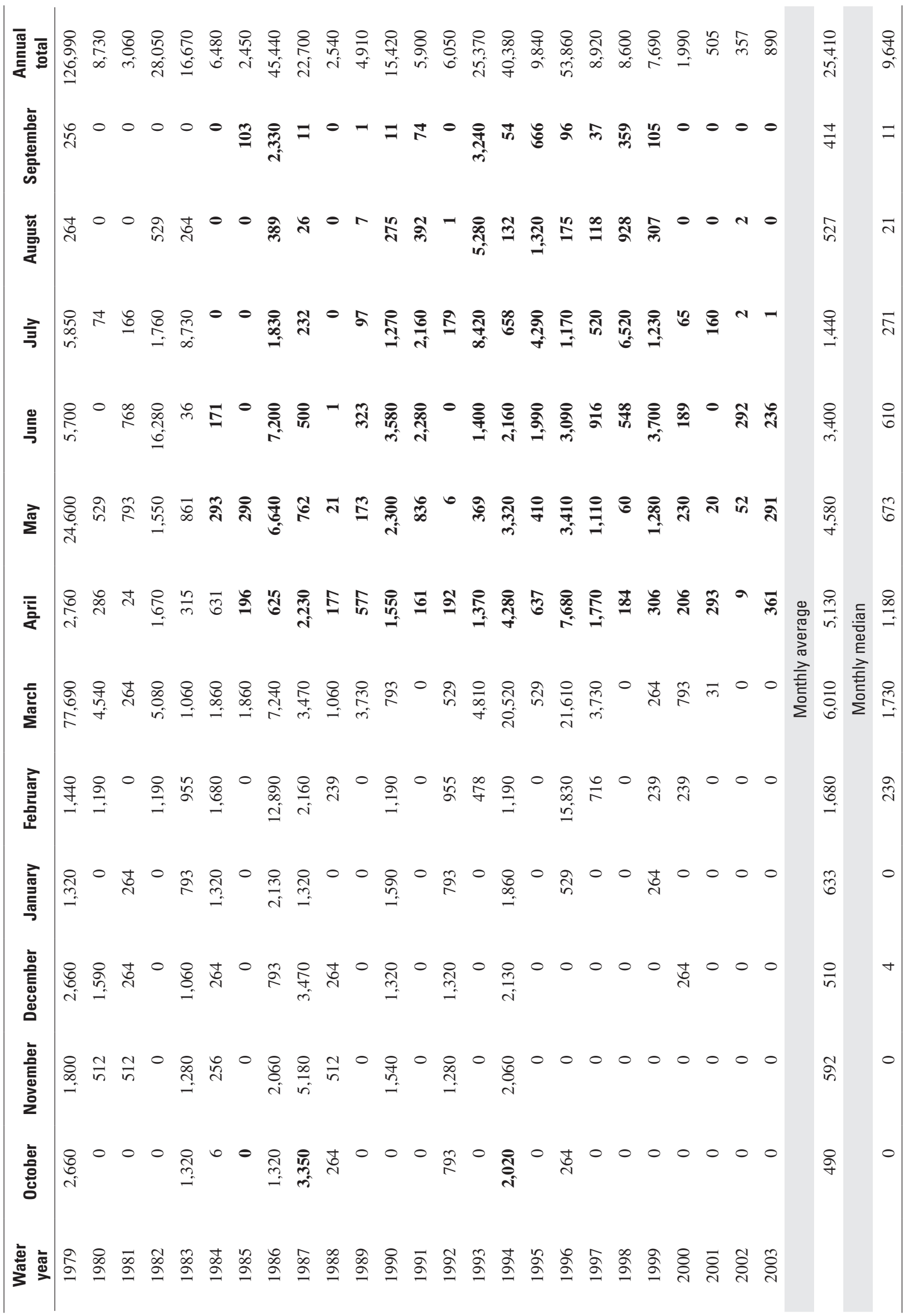




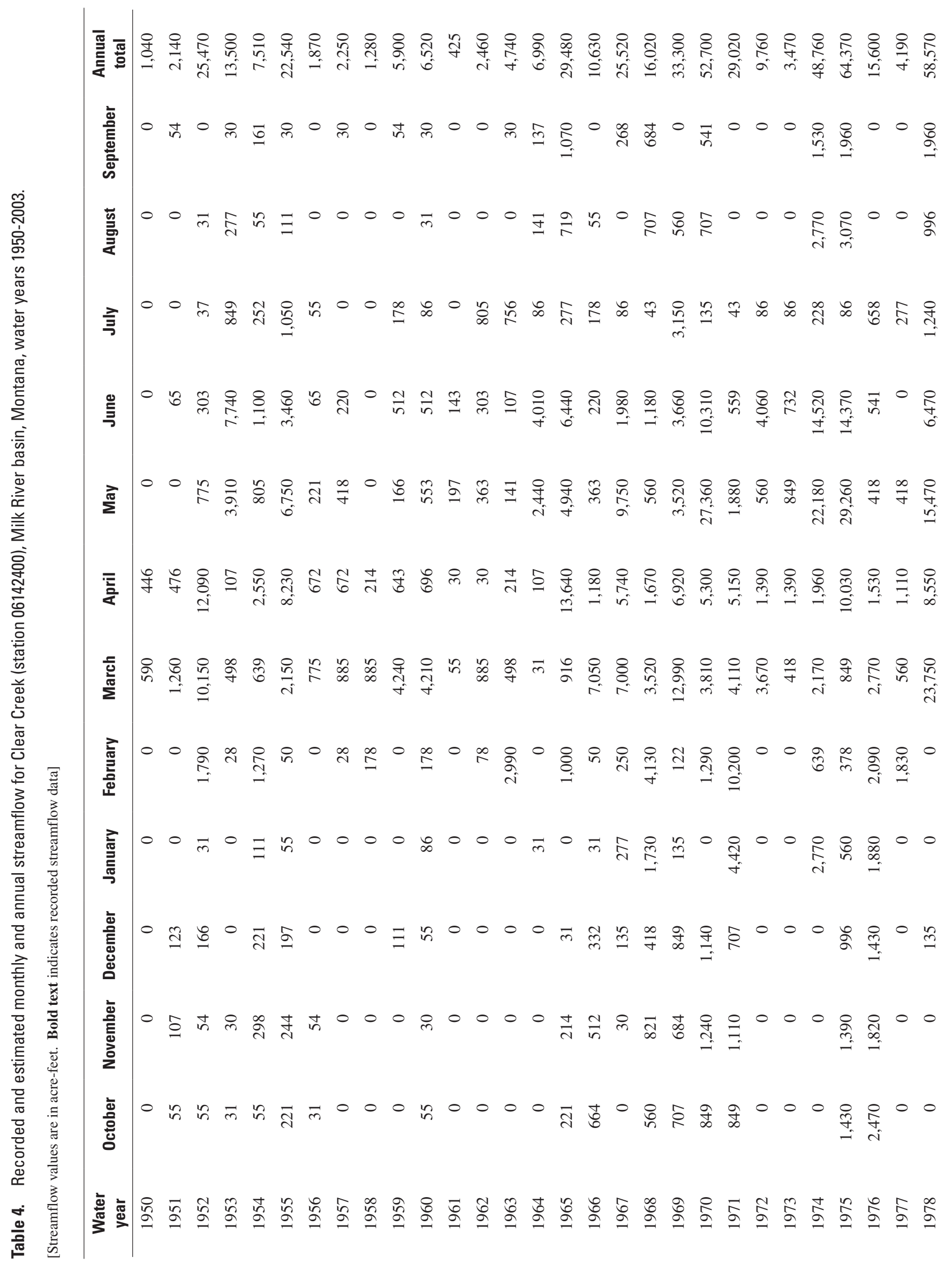




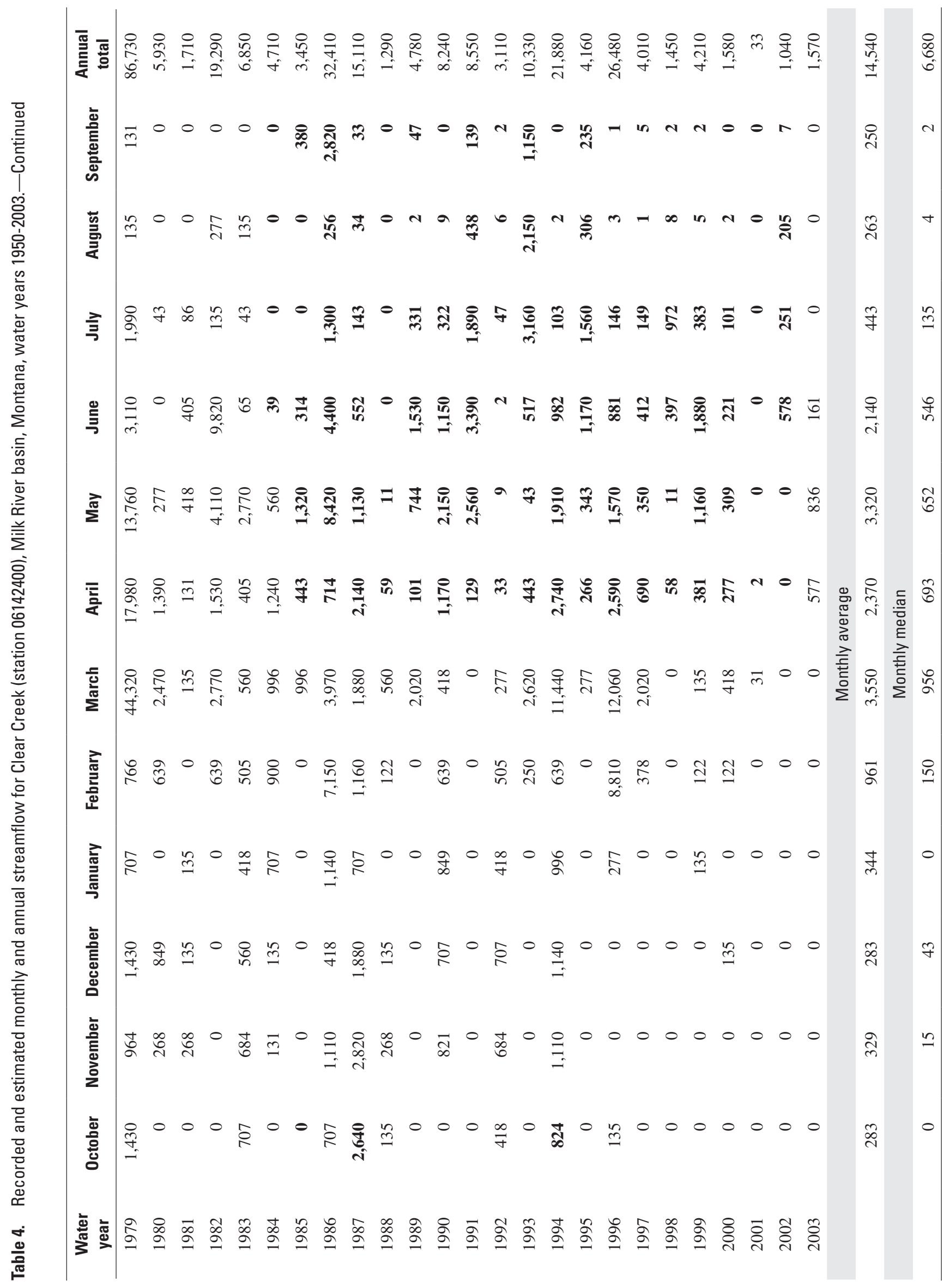




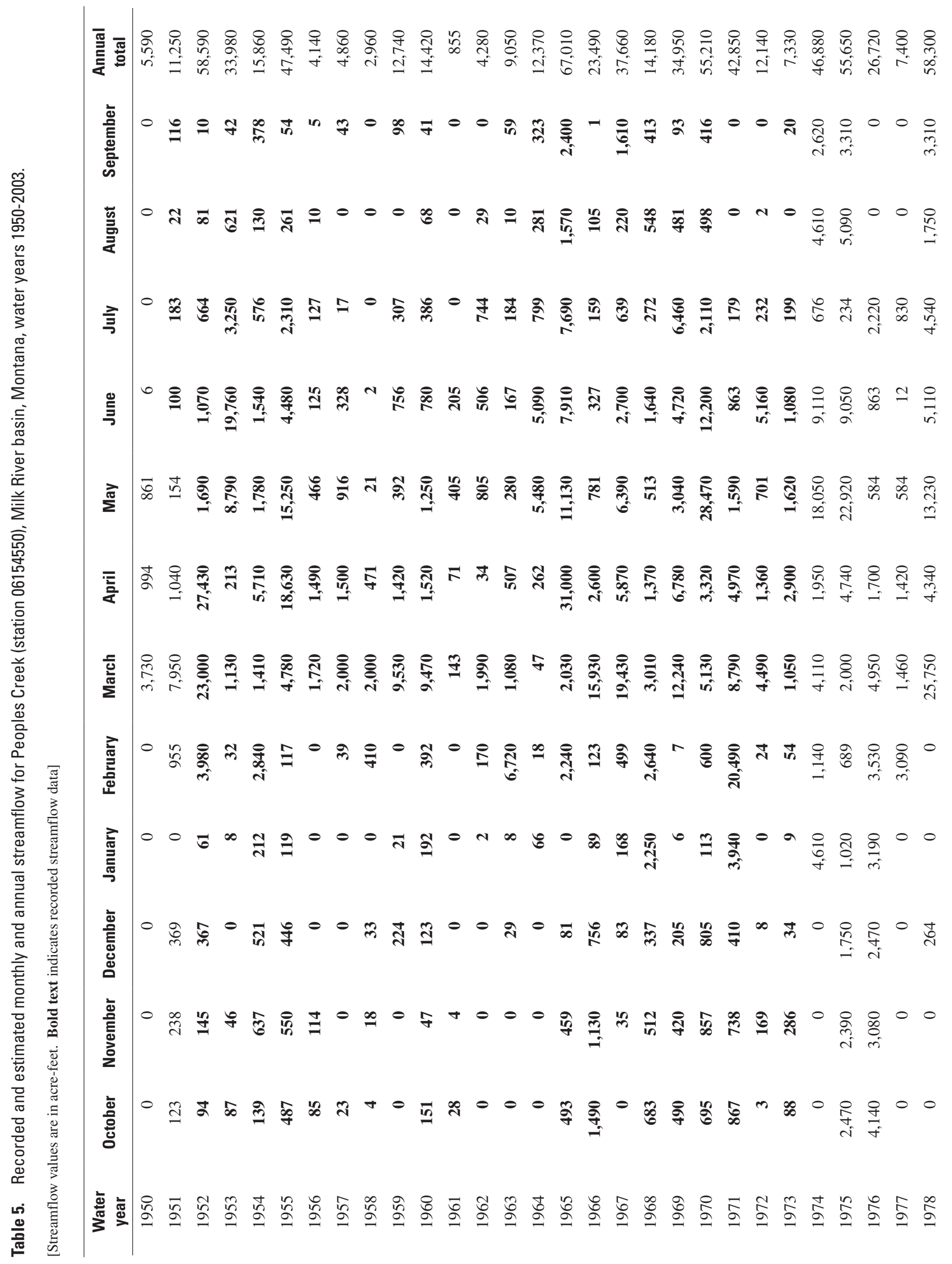




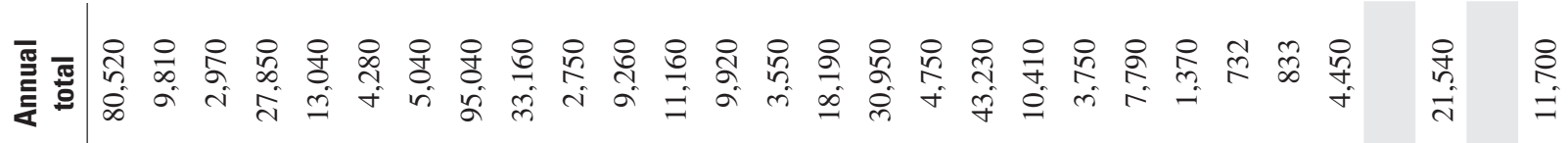

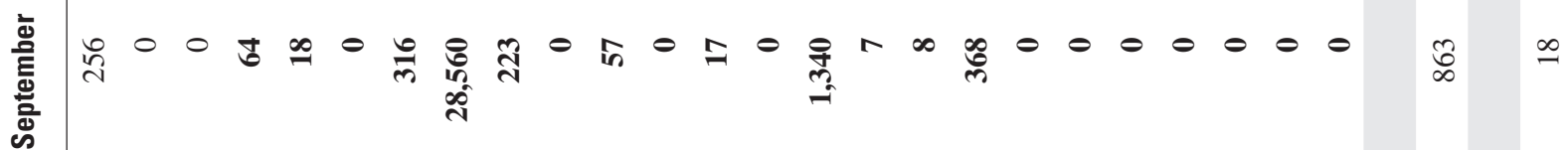

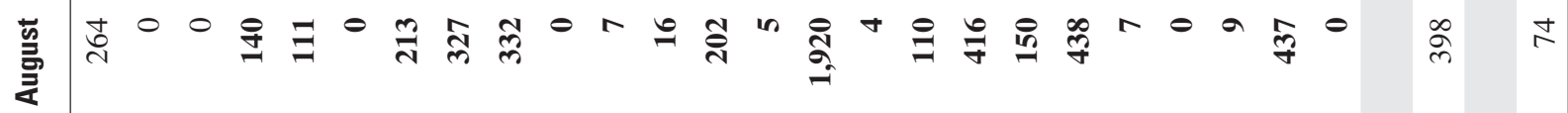

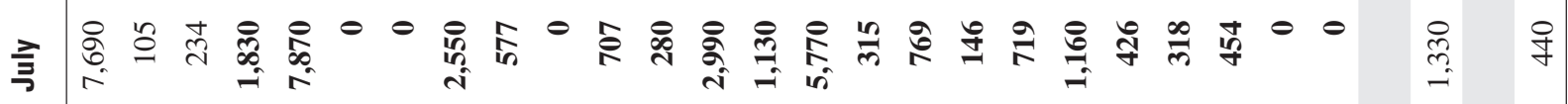

吉

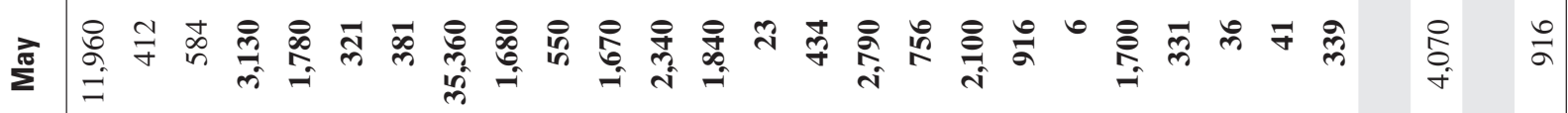

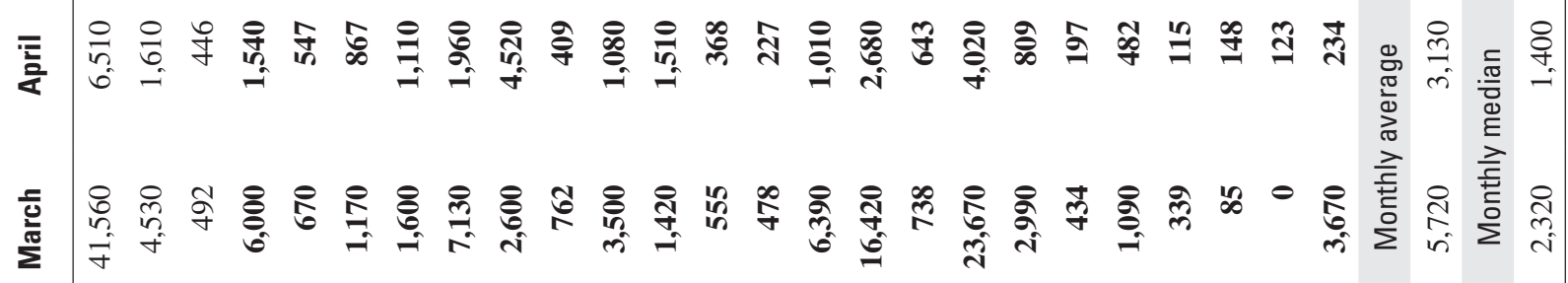

壼

䔍

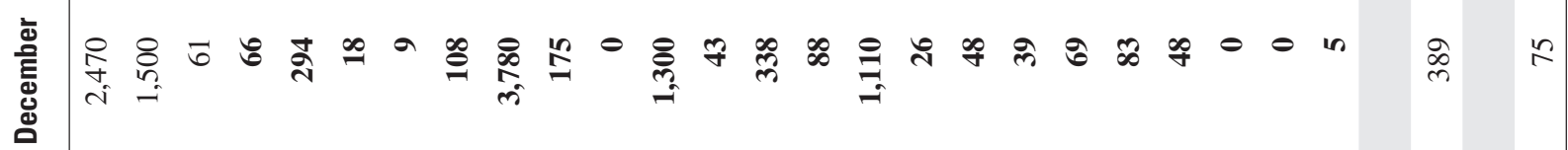
产 总 总 


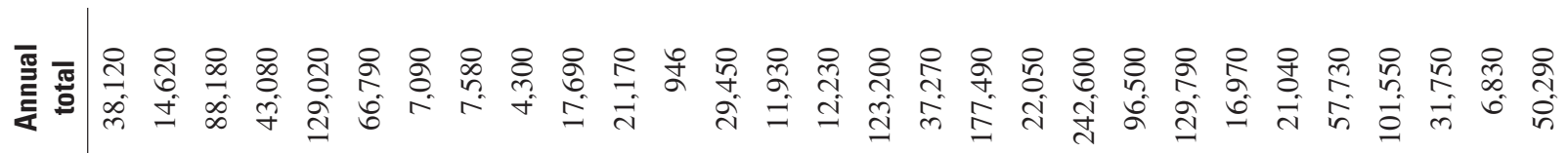

$$
\begin{aligned}
& \text { 产 }
\end{aligned}
$$

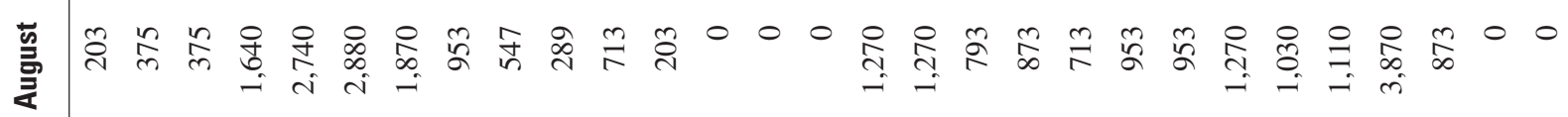

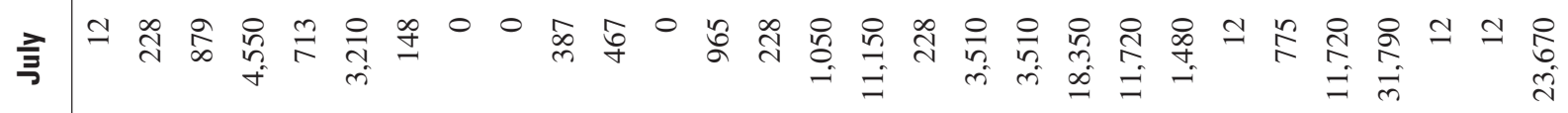

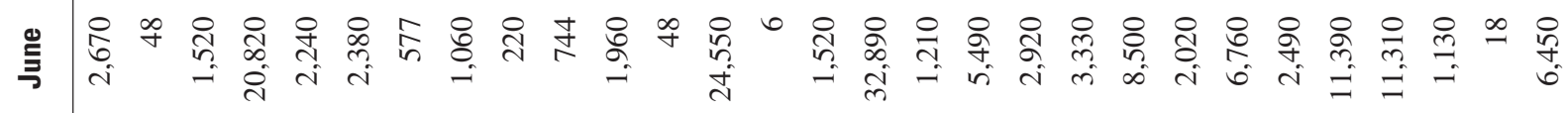

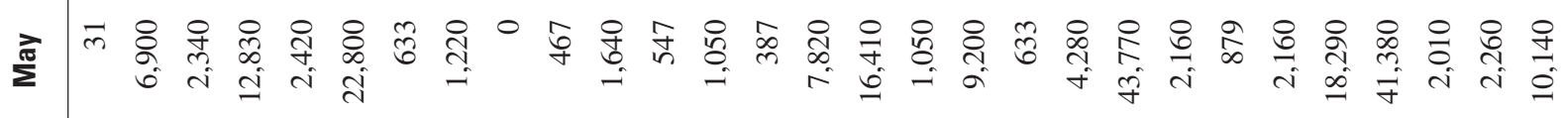

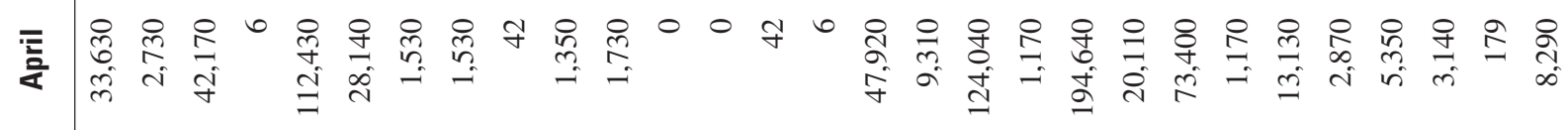

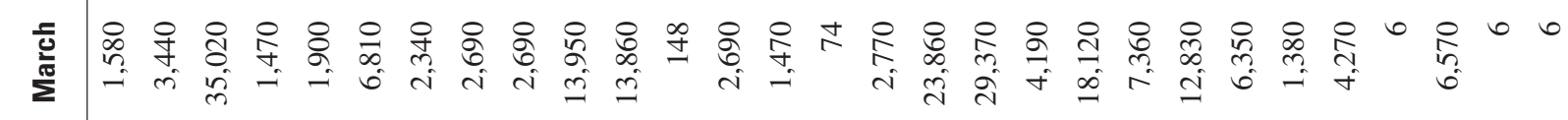

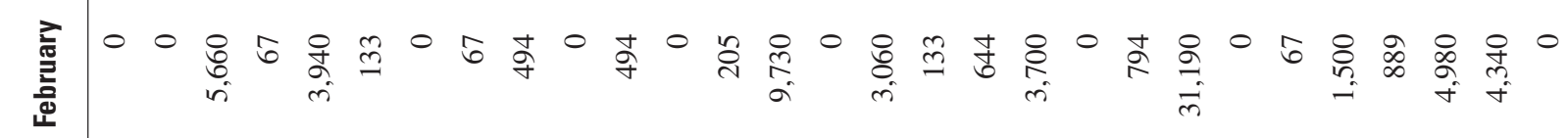

$$
\begin{aligned}
& \text { 至 }
\end{aligned}
$$

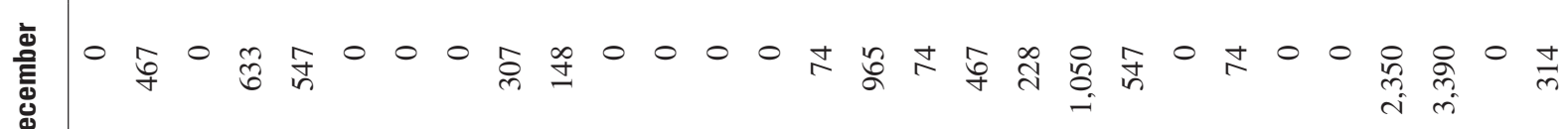

$$
\begin{aligned}
& \text { 窇 }
\end{aligned}
$$

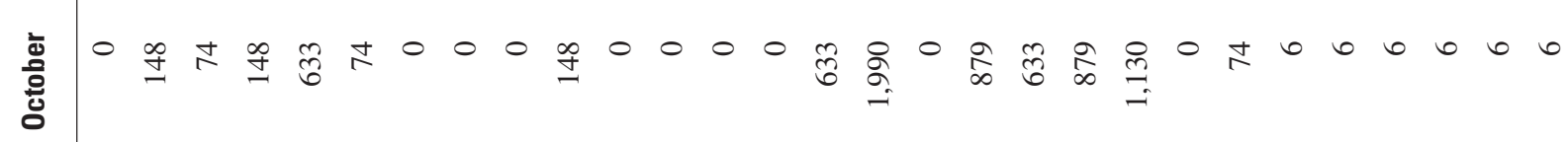

$$
\begin{aligned}
& \text { 离离 }
\end{aligned}
$$




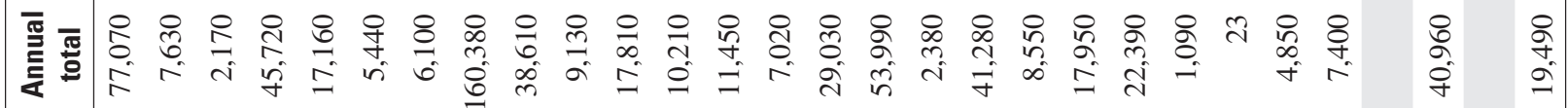

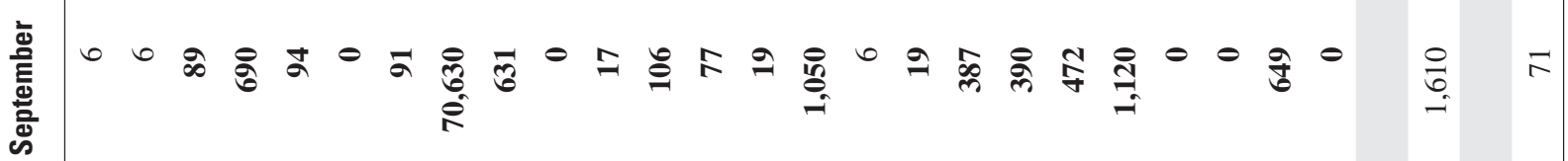

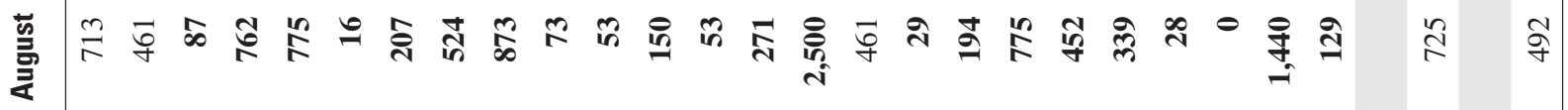

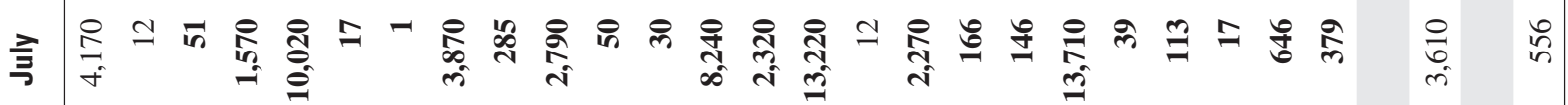

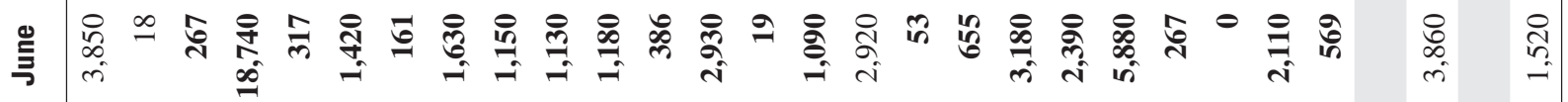

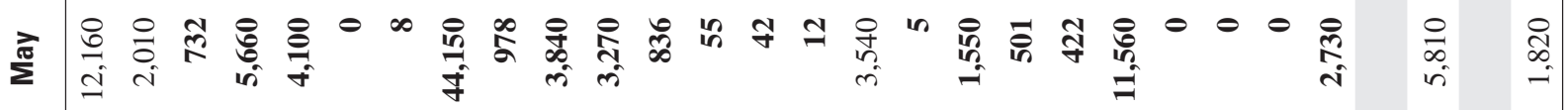

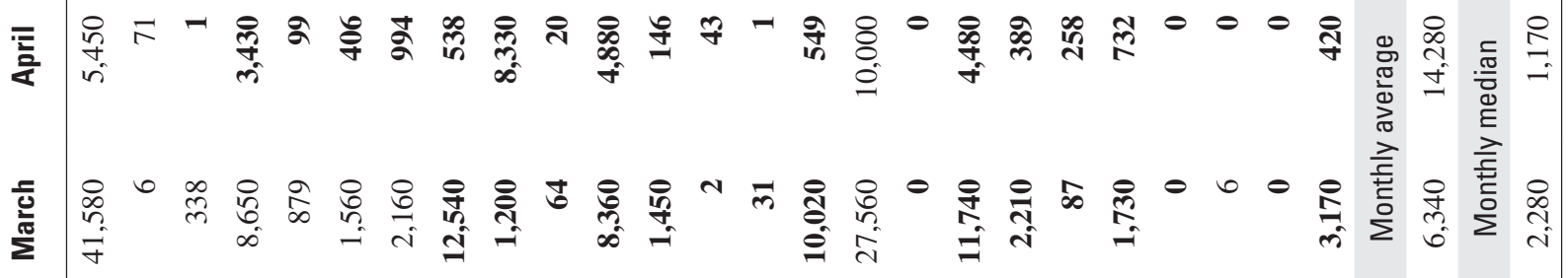
竞

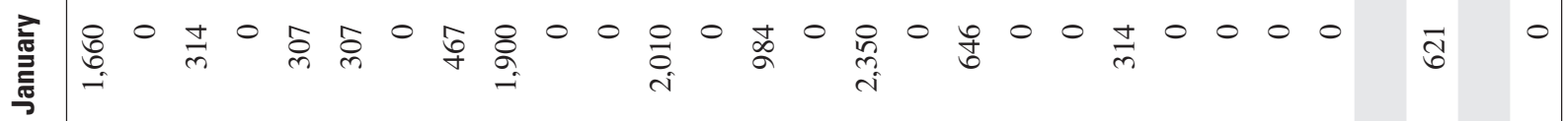

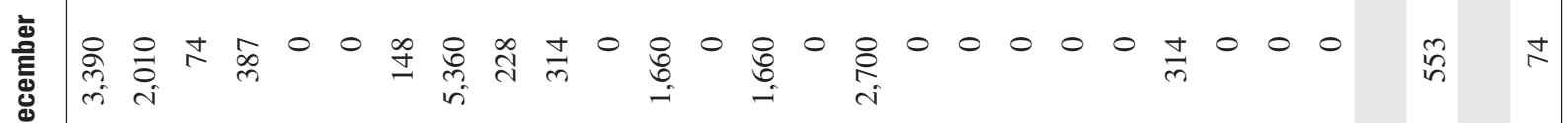

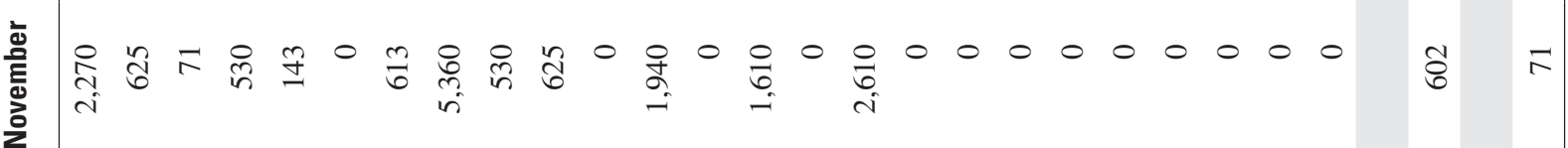
竎

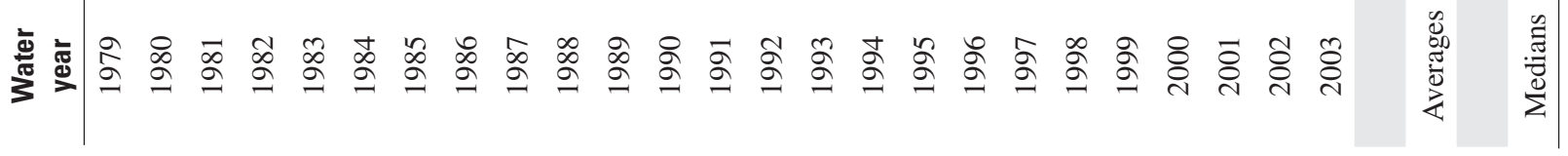




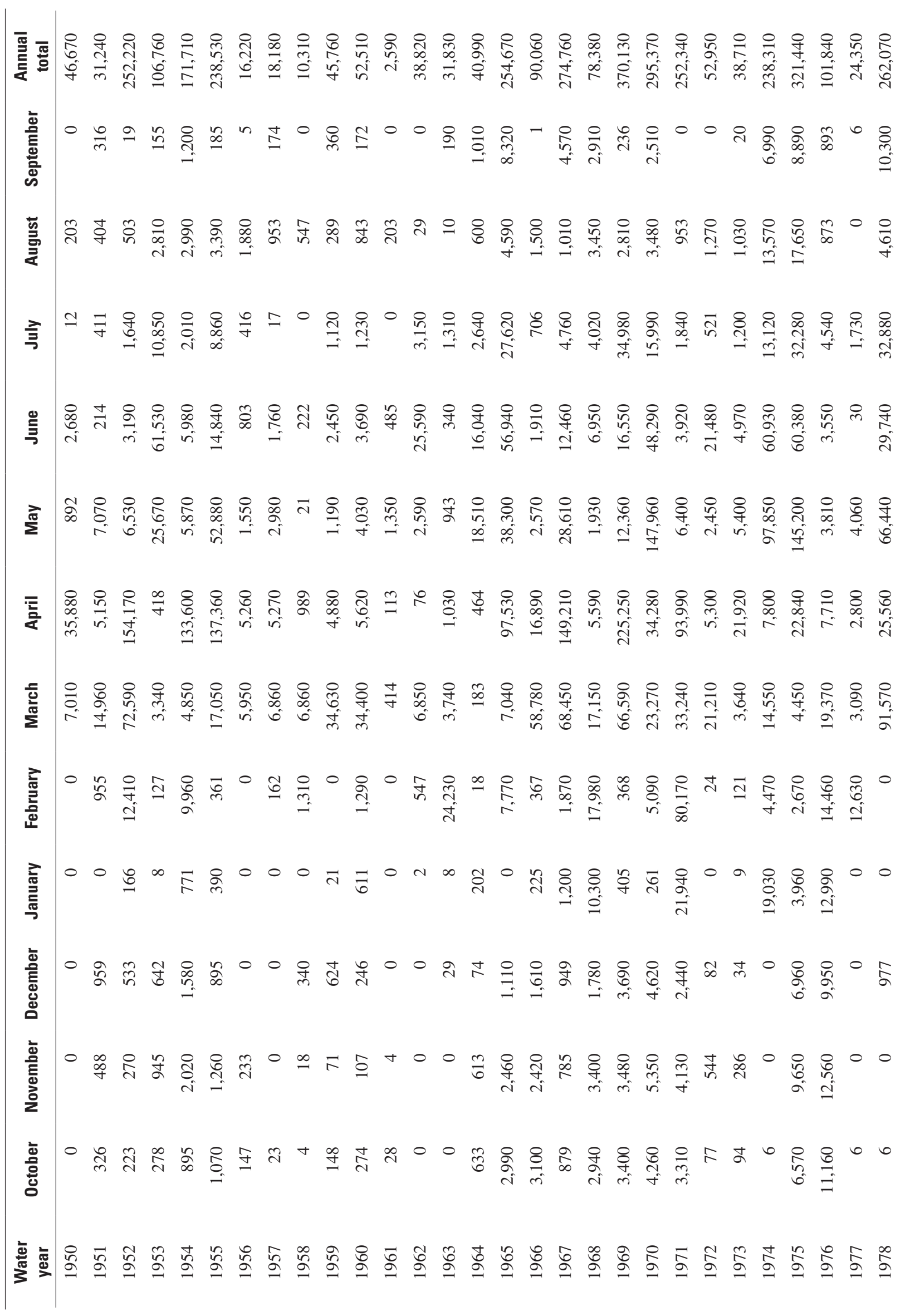




\begin{tabular}{|c|c|c|c|c|c|c|c|c|c|c|c|c|c|c|c|c|c|c|c|c|c|c|c|c|c|c|c|c|c|}
\hline 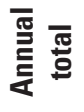 & $\mid \begin{array}{ll}0 & 8 \\
m & 8 \\
\underset{m}{m} & \text { mi }\end{array}$ & & 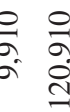 & 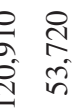 & 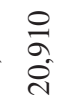 & 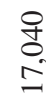 & $\begin{array}{l}\stackrel{2}{N} \\
\text { mે } \\
\text { m }\end{array}$ & $\begin{array}{l}8 \\
\infty \\
2 \\
8 \\
0\end{array}$ & 울 & & 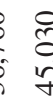 & $\begin{array}{ll}0 & 0 \\
0 & 0 \\
f & 0 \\
f & m\end{array}$ & $\begin{array}{cc}0 \\
0 \\
0 & 5 \\
0 & 0\end{array}$ & 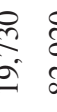 & & 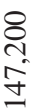 & 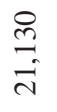 & 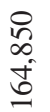 & $\begin{array}{l}\stackrel{\circ}{\infty} \\
\text { m. }\end{array}$ & 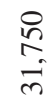 & & & & & 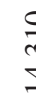 & & & & $\begin{array}{l}8 \\
\dot{y} \\
\text { f }\end{array}$ \\
\hline 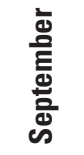 & gे & & $\infty$ & $\stackrel{\Xi}{\beth}$ & 0 & $\stackrel{\infty}{\infty}$ & $\begin{array}{l}\stackrel{P}{\mathrm{f}} \\
\stackrel{+}{0}\end{array}$ & & 0 & & & $E$ 㝏 & & & . & & 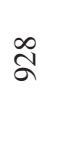 & $\tilde{\infty}$ & $\stackrel{\widetilde{f}}{f}$ & $\aleph_{\infty}$ & r & & & & & & $\frac{q}{d}$ & & $\stackrel{\infty}{\infty}$ \\
\hline 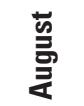 & 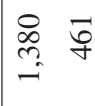 & & $\infty$ & $=\stackrel{2}{2} \stackrel{8}{=}$ & 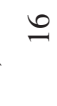 & $\stackrel{\Im}{\Im}$ & $\stackrel{8}{\stackrel{8}{n}}$ & $\stackrel{尺}{\stackrel{ }{ت}}$ & $\stackrel{2}{2}$ & $g$ & & 8 & & 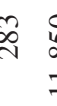 & & हे & $\stackrel{?}{\stackrel{2}{ }}$ & $\stackrel{\infty}{\stackrel{\infty}{\sim}}$ & $\stackrel{\text { f }}{\text { S }}$ & $\underset{\infty}{\infty}$ & \begin{tabular}{l}
$\infty$ \\
\multirow{2}{c}{}
\end{tabular} & & & & & & $\frac{0}{\sigma}$ & & $\tilde{n}$ \\
\hline $\overrightarrow{\bar{g}}$ & $\begin{array}{l}\stackrel{丶}{尺} \\
\stackrel{\overbrace{}}{2}\end{array}$ & & 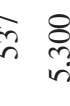 & 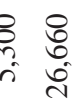 & $=$ & - & $\begin{array}{l}\text { Rे } \\
\text { ñ }\end{array}$ & $\stackrel{9}{\stackrel{9}{4}}$ & $\stackrel{\circ}{\stackrel{ి}{i}}$ & 5 & ๕ & 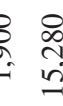 & & $\begin{array}{cc} & \\
0 & 1 \\
0 & 4 \\
m & \\
m & \end{array}$ & & ఏ. & $\begin{array}{l}\text { Oे } \\
\infty \\
\infty \\
\infty\end{array}$ & ס્ & in & $\begin{array}{l}\text { d } \\
\text { लn } \\
\text { di }\end{array}$ & $\begin{array}{l}0 \\
\stackrel{0}{c} \\
i\end{array}$ & & & & $\oint$ & & $\begin{array}{c}0 \\
\infty \\
0\end{array}$ & & $\stackrel{2}{\stackrel{2}{2}}$ \\
\hline$\stackrel{\circlearrowright}{\Xi}$ & 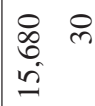 & $\frac{5}{9}$ & $\begin{array}{ll}o & 8 \\
\text { If } & \text { in } \\
\text { in } & \end{array}$ & 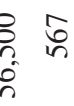 & $\stackrel{尺}{\stackrel{0}{\approx}}$ & oे & 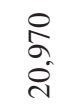 & $\begin{array}{l}\text { शे } \\
\text { ले }\end{array}$ & $\stackrel{\text { f }}{=}$ & 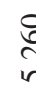 & ฮ్ & 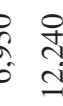 & & $\vec{\Delta}$ & 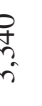 & $\begin{array}{l}\stackrel{\circ}{\alpha} \\
\text { aे }\end{array}$ & $\begin{array}{l}\stackrel{8}{1} \\
\stackrel{+}{f}\end{array}$ & 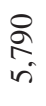 & $\begin{array}{l}\text { के } \\
\text { n. }\end{array}$ & $\stackrel{?}{+}$ & $\begin{array}{l}8 \\
\dot{j}\end{array}$ & & & $=$ & $\$$ & & ஓ & & $\stackrel{8}{\circ}$ \\
\hline$\sum^{\vec{\pi}}$ & 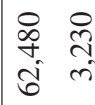 & 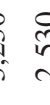 & 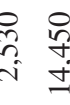 & 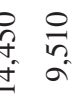 & $\stackrel{8}{=}$ & $\stackrel{8}{\mathrm{~d}}$ & $\begin{array}{l}? \\
\text { in } \\
\text { f }\end{array}$ & $\begin{array}{l}8 \\
n \\
r\end{array}$ & 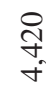 & $\begin{array}{l}\text { d } \\
\text { d } \\
\text { in }\end{array}$ & हె & 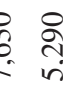 & & & $\overbrace{0}^{\infty}$ & $\begin{array}{l}8 \\
\stackrel{8}{0} \\
= \\
=\end{array}$ & $\stackrel{0}{\stackrel{n}{n}}$ & $\begin{array}{l}\text { त్ } \\
\text { ¿. }\end{array}$ & $\begin{array}{l}\infty \\
\infty \\
\infty \\
i\end{array}$ & बे & $\stackrel{8}{\circledR}$ & $\alpha$ & & & 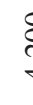 & & 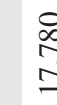 & & $\stackrel{\circ}{\stackrel{m}{f}}$ \\
\hline 产 & $\begin{array}{ll}\stackrel{8}{R} & \stackrel{0}{0} \\
\text { in } & \text { m. }\end{array}$ & & $\delta_{0}^{1} \frac{\Omega}{\infty}$ & 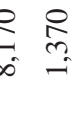 & $\frac{g}{m}$ & $\stackrel{9}{\stackrel{9}{i}}$ & $\begin{array}{l}\stackrel{9}{+} \\
\infty \\
\text { ri }\end{array}$ & $\begin{array}{l}\text { ปิ } \\
\text { İ }\end{array}$ & $\tilde{d}$ & gु & $\underset{\sim}{\infty}$ & 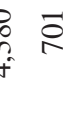 & & 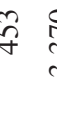 & $\begin{array}{l}\frac{p}{n} \\
n \\
r\end{array}$ & 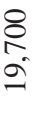 & $\begin{array}{l}8 \\
\stackrel{n}{n} \\
=\end{array}$ & 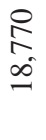 & $\begin{array}{l}8 \\
: \\
\stackrel{0}{0}\end{array}$ & $\hat{\hat{\sigma}}$ & ङ & & & & 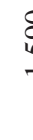 & & $\begin{array}{ll}0 \\
0 \\
0 \\
0 \\
0 \\
0 \\
0\end{array}$ & 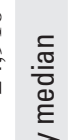 & $\begin{array}{l}\stackrel{0}{0} \\
\text { in }\end{array}$ \\
\hline $\begin{array}{l}\overline{\bar{\nu}} \\
\text { एँ }\end{array}$ & 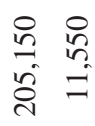 & & 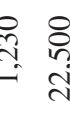 & th & $\begin{array}{l}8 \\
\text { in } \\
\text { in }\end{array}$ & त్ర్రి & $\begin{array}{l}\infty \\
\infty \\
\infty \\
0 \\
0\end{array}$ & $\frac{8}{a}$ & $\stackrel{8}{+}$ & $\frac{c}{b}$ & $\stackrel{\infty}{\varnothing}$ & $\begin{array}{l}0 \\
0 \\
0\end{array}$ & ई & 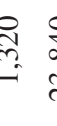 & $\begin{array}{l}q \\
0 \\
i \\
i v\end{array}$ & $\begin{array}{l}\text { +े } \\
\text { à } \\
\text { ñ }\end{array}$ & 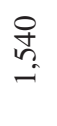 & $\begin{array}{l}\mathscr{0} \\
: \\
8\end{array}$ & $\begin{array}{l}\stackrel{0}{2} \\
\hat{0} \\
0\end{array}$ & $\overrightarrow{\tilde{n}}$ & $\begin{array}{l}\text { సิ } \\
\text { }\end{array}$ & & is & & 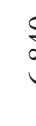 & 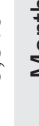 & $\bar{\Xi}$ & $\sum^{\bar{E}}$ & ণ్ హิ \\
\hline 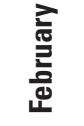 & $\begin{array}{ll}0 & ? \\
\infty & ? \\
i & f \\
i n & f\end{array}$ & & $\begin{array}{l}0 \\
0 \\
0\end{array}$ & 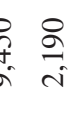 & $\begin{array}{l}\stackrel{8}{?} \\
\text { in }\end{array}$ & $\stackrel{8}{\circ}$ & $\begin{array}{l}\stackrel{8}{0} \\
0 \\
\stackrel{f}{f}\end{array}$ & $\begin{array}{l}\infty \\
\infty \\
\infty \\
i\end{array}$ & ฮิ & & ळे & है & 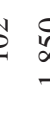 & $\begin{array}{l}\infty \\
\infty \\
\infty \\
- \\
-\end{array}$ & $\begin{array}{c}2 \\
D_{1}\end{array}$ & $\begin{array}{l}\stackrel{1}{c} \\
\infty \\
m\end{array}$ & $\tilde{\Theta}$ & $\begin{array}{l}\frac{8}{n} \\
\text { nn }\end{array}$ & $\stackrel{\circ}{\stackrel{7}{*}}$ & $\stackrel{\infty}{-}$ & $\stackrel{9}{=}$ & $y$ & 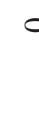 & & & & ?ִ & & \& \\
\hline 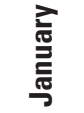 & \begin{tabular}{ll}
0 & 0 \\
& \\
\multirow{+}{*}{} &
\end{tabular} & & $\hat{\sigma}$ & $\sqrt{\stackrel{9}{I}}$ & $\begin{array}{l}8 \\
\stackrel{0}{0} \\
\text { i }\end{array}$ & 0 & $\stackrel{8}{8}$ & ले & $\stackrel{0}{0}$ & & $\begin{array}{l}\text { ลे } \\
\text { is }\end{array}$ & $\begin{array}{ll}x & 0 \\
y & 0 \\
r\end{array}$ & S & $\begin{array}{cc}8 \\
\substack{8 \\
0 \\
i}\end{array}$ & $\hat{n}$ & $\begin{array}{l}\text { के } \\
\text { ni }\end{array}$ & $\bar{\gamma}$ & . & in & $\tilde{\lambda}$ & $\stackrel{8}{m}$ & 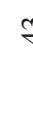 & . & & & & घ̃ & & $\stackrel{\infty}{+}$ \\
\hline 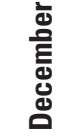 & 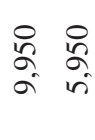 & & $\begin{array}{ll}\tilde{n} \\
\tilde{n}\end{array}$ & $\hat{f} \stackrel{\circ}{\sigma}$ & 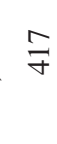 & $\hat{n}$ & $\underbrace{\circ}_{0}$ & $\begin{array}{l}8 \\
\text { ñ } \\
\sigma\end{array}$ & $\begin{array}{l}\infty \\
\infty \\
\infty\end{array}$ & & \& & $\underset{f}{f}$ & $f$ & $\begin{array}{c}8 \\
0 \\
f \\
f\end{array}$ & $\infty$ & $\begin{array}{l}\infty \\
\stackrel{0}{\circ}\end{array}$ & $\stackrel{i}{~}$ & $\stackrel{\infty}{+}$ & ले & 8 & $\infty$ & 5 & & & & & लิ & & $\tilde{q}$ \\
\hline 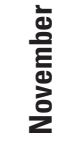 & 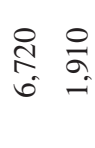 & & $\bar{\sigma}$ & 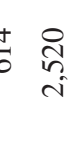 & $\bar{n}$ & $\frac{\nabla}{\sigma}$ & $\begin{array}{l}\stackrel{8}{\circ} \\
\text { ळे }\end{array}$ & $\begin{array}{l}\stackrel{0}{m} \\
\stackrel{m}{c}\end{array}$ & $\stackrel{\infty}{\infty}$ & & స్ & th & $\begin{array}{l}2 \\
2 \\
2 \\
2\end{array}$ & 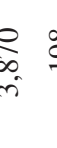 & 2 & $\begin{array}{l}\text { ڤे } \\
\text { के }\end{array}$ & nิ & $\stackrel{\oplus}{\oplus}$ & r & $\cong$ & ప & & & 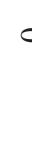 & & & 1 & & $\frac{0}{n}$ \\
\hline $\begin{array}{l}\text { పू } \\
\text { 음 }\end{array}$ & $\begin{array}{l}\stackrel{2}{n} \text { ส } \\
\text { b. }\end{array}$ & & 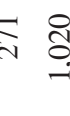 & 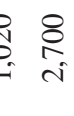 & $\stackrel{\infty}{m}$ & 0 & \begin{tabular}{l}
$\stackrel{8}{\circ}$ \\
\multirow{f}{*}{}
\end{tabular} & $\begin{array}{l}\text { 음 } \\
\text { ले }\end{array}$ & 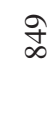 & & $\stackrel{c}{0}$ & $\stackrel{\infty}{\circ}$ & 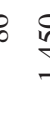 & $\stackrel{8}{i}$ & y & 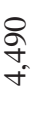 & $\cong$ & $\begin{array}{l}\infty \\
\stackrel{\infty}{n} \\
=\end{array}$ & a & $\bar{\Xi}$ & $\approx$ & & & & & & & & 守 \\
\hline 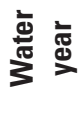 & 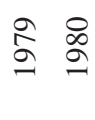 & & $\stackrel{5}{\infty}$ & $\stackrel{\widetilde{\mathscr{O}}}{=}$ & $\stackrel{\ddagger}{\stackrel{\Xi}{\leftrightharpoons}}$ & $\stackrel{\mathscr{O}}{2}$ & $\stackrel{\circ}{\varrho}$ & $\stackrel{\infty}{\sigma}$ & $\stackrel{\infty}{\infty}$ & $\alpha$ & ஓ & 2 & $\S$ & $\hat{\sigma} \delta$ & $\hat{\Omega}$ & बू & $\stackrel{n}{\sigma}$ & ஃั & ลิ & $\stackrel{\infty}{\circ}$ & & & & & & & & & 胥 \\
\hline
\end{tabular}


For additional information contact:

Director, Montana Water Science Center

U.S. Geological Survey

3162 Bozeman Avenue

Helena, Montana 59601

Telephone: 1-406-457-5900

World Wide Web: http://mt.water.usgs.gov/ 